Review

\title{
Genetic Engineering for Global Food Security: Photosynthesis and Biofortification
}

\author{
Andrew John Simkin 1 \\ Genetics, Genomics and Breeding, NIAB EMR, East Malling, Kent ME19 6BJ, UK; \\ andrew.simkin@emr.ac.uk; Tel.: +44-01732-52-3748
}

Received: 19 November 2019; Accepted: 5 December 2019; Published: 9 December 2019

check for

updates

\begin{abstract}
Increasing demands for food and resources are challenging existing markets, driving a need to continually investigate and establish crop varieties with improved yields and health benefits. By the later part of the century, current estimates indicate that a $>50 \%$ increase in the yield of most of the important food crops including wheat, rice and barley will be needed to maintain food supplies and improve nutritional quality to tackle what has become known as 'hidden hunger'. Improving the nutritional quality of crops has become a target for providing the micronutrients required in remote communities where dietary variation is often limited. A number of methods to achieve this have been investigated over recent years, from improving photosynthesis through genetic engineering, to breeding new higher yielding varieties. Recent research has shown that growing plants under elevated $\left[\mathrm{CO}_{2}\right]$ can lead to an increase in Vitamin $\mathrm{C}$ due to changes in gene expression, demonstrating one potential route for plant biofortification. In this review, we discuss the current research being undertaken to improve photosynthesis and biofortify key crops to secure future food supplies and the potential links between improved photosynthesis and nutritional quality.
\end{abstract}

Keywords: photosynthesis; biofortification; yield; nutrition

\section{Introduction}

Over the last 70 years, agricultural yields have risen at a level that meets global demand. Most of these increases came about from the breeding of higher yielding varieties and advances in agronomic approaches [1], as well as improving yields by exploiting the natural photosynthetic variation in key crops [2,3]; however, more recently the yields of several important food crops have plateaued. By 2050, it is expected that the global population will exceed 9 billion [4,5]. To meet the ever-growing requirements for both food and fuel, it will be necessary to develop new varieties of crops with higher yields [6-9]. It has been estimated that a $70 \%$ to a $100 \%$ increase in the yield of crops such as wheat, soybean (Glycine max) and maize (Zea mays) will be required to meet these needs [10-12]. One avenue, clearing land for crop production, has the significant drawback of causing environmental damage to unique habitats, resulting in a global loss in biodiversity [13-16]. Increasing cultivatable land also comes at the cost of increased fertiliser and pesticide use which creates further damage to both marine and freshwater ecosystems [17] and results in a significant increase in greenhouse gas emissions [18]. To mitigate environmental damage, it will be necessary to meet global food demands without increasing the amount of cultivatable land. To increase yields whilst protecting the environment, the development of new varieties of key crops is essential. This may be achieved through improving photosynthesis through genetic manipulation (Section 2).

In addition to increasing crop yields, there is also a need to improve the nutritional quality. Over the last 5 decades, new crop varieties have increased production of calorie dense staple crops but the production of non-staple micronutrient-rich crops has not increased. Additionally, the food prices of micronutrient-rich non-staple crops such as fruits and vegetable and important animal products have 
increased, leaving poorer communities financially unable to obtain the variability needed for a healthy diet [19]. Globally, micronutrient deficiencies affect more than two billion people [4]. Micronutrient deficiencies are the direct result of poor diet where vitamins and minerals are below the threshold to sustain a healthy lifestyle [19]. Through biofortification (Section 3), there is potential to improve the bioavailability of important nutrients in new crops.

In this review, I will discuss a multi-targeted approach to increasing photosynthetic efficiency and a targeted approach to the generation of multi-vitamin crops and the potential links between boasting photosynthesis and impact on the final vitamin content of modified crops.

\section{Photosynthesis}

Photosynthesis is responsible, either directly through plant growth or indirectly through the food chain, for all the food consumed worldwide. Furthermore, all the fuel derived from oil was originally derived from photosynthates and accounts for as much as $90 \%$ of current energy production [20]. Crop yield is determined by the collective rate of photosynthesis over the growing season. A key determinant of this is the efficiency at which light is A, captured and B, converted into yield (i.e., biomass or grain). Carbon assimilation in plants involves two closely associated pathways, 1 , the Calvin-Benson cycle (CBC) and 2, Photorespiration. These pathways are centred on the catalytic activity of Rubisco (ribulose-1,5-bisphosphate carboxylase/oxygenase; R; Figure 1), a complex stromal enzyme which accounts for more than $50 \%$ of all leaf protein and $25 \%$ of leaf nitrogen. Found in all photosynthetic organisms, Rubisco has been identified as a target for genetic manipulation and has thus been widely reviewed to date [21]. Enhancing photosynthesis, electron transport and photorespiration has been accepted as a key target for increasing crop productivity [22-24]. A recent comprehensive review by Simkin et al. [23] has touched upon this potential. In this review, we will focus on the impact of a multi-target approach to improving photosynthesis and potential impacts on nutrient value of transformed crops.

\subsection{Manipulation of Calvin-Benson Cycle}

The $\mathrm{CBC}$ is subdivided into three stages, carboxylation, reduction and regeneration. The cycle, elucidated by Melvin Calvin et al. in the 1950s [25,26], involves 11 enzymes, which catalyse 13 different steps (Figure 1). Transgenic studies have demonstrated any decrease in any one of the key enzymes of the CBC has a significant negative impact on the rate of carbon assimilation and plant growth. These studies have shown that reductions in sedoheptulose-1,7-bisphosphatase (SBPase) [27-29], fructose-1,6-bisphosphate aldolase (FBPA) [30,31], fructose-1,6-bisphosphatases (FBPase) [32-34] or phosphoribulokinase [35] resulted in a decrease in final biomass yield. The results of these experiments showed that there are multiple limiting steps within the $\mathrm{CBC}$ and that increasing enzyme activities at any of these branch points has the potential to boost photosynthetic efficiency and as a consequence increase yields [36,37]. Furthermore, $\left[\mathrm{CO}_{2}\right]$ enrichment experiments in field-based studies demonstrated that increasing $\mathrm{CO}_{2}$ assimilation results in increases in plant biomass [38]. 


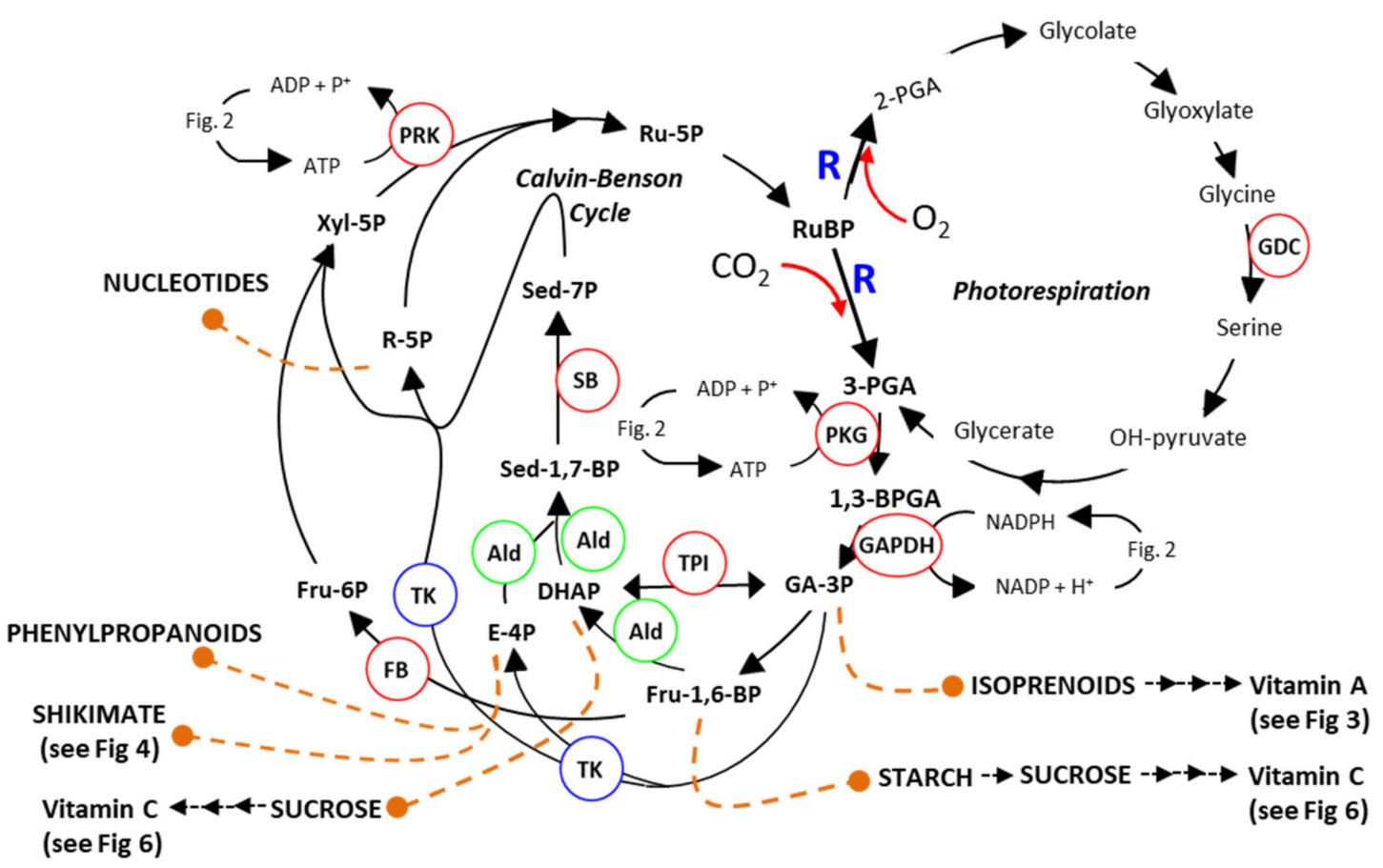

Figure 1. Schematic Representation of Photosynthesis and Photorespiration. Sedoheptulose-1,7bisphosphatase (SB: EC.3.1.3.37), fructose-1,6-bisphosphate aldolase (Ald: EC.4.1.2.13), fructose-1,6bisphosphatases (FB: EC.3.1.3.11), triosephosphate isomerase [TPI: EC 5.3.1.1], transketolase (TK: EC.2.2.1.1), phosphoribulokinase (PRK: EC.2.7.1.19), phosphoglycerate kinase (PGK: EC.2.7.2.3), ribulose-bisphosphate carboxylase (R: EC.4.1.1.39), Glyceraldehyde-3-phosphate dehydrogenase (GAPDH) and Glycine decarboxylase (GDC). (see [39]).

Early work targeting single steps in the $\mathrm{CBC}$ was used to test the potential for increasing the rates of $\mathrm{CO}_{2}$ assimilation and evaluating their effects on plant development and biomass yield. For example, the over-expression of SBPase in tobacco (Nicotiana tabacum) [40,41], Arabidopsis (Arabidopsis thaliana) [42] and tomato (Solanum lycopersicum) [43] has shown that an increase in SBPase enzyme activity results in significant increases plant biomass ( $>30 \%$ increase in biomass). In follow-up work, increased SBPase activity in tobacco grown in open-air elevation of $\left[\mathrm{CO}_{2}\right]$ experiments led to substantial increases in biomass yield [44]. More recently, the over-expression of SBPase in wheat, an important food crop, resulted in an increase in biomass yield and more importantly, a 30\% to $40 \%$ increase in seeds yield [45]. Similar results were obtained by the over-expression of another CBC enzyme, FBPA, where an increase in biomass of $70-120 \%$ was observed under elevated $\left[\mathrm{CO}_{2}\right](700 \mathrm{ppm})$ [46]. However, recent work in tobacco showed that the over-expression of some CBC enzymes is not beneficial. The over-expression of transketolase, for example, led to a negative effect on plant development and plants regularly showed a chlorotic phenotype and retarded growth [47].

Work showing that the manipulation of individual enzymes can result in an increase in yield has been further investigated through the targeting of multiple enzymatic steps in CBC. For example, the over-expression of SBPase and FBPA in transgenic tobacco resulted in a cumulative increase in biomass yield (+62\%) compared to plants expressing SBPase alone (+34\%) [41], demonstrating that multigene manipulation of the $\mathrm{CBC}$ can lead to additional increases in yield. However, over-expression of SBPase and FBPA in transgenic Arabidopsis did not lead to a synergistic effect and the observed increases in biomass were similar between SBPase, FBPA and SBPase + FBPA expressing lines [42]. These contradictory results indicate that different targeted manipulations will be needed, depending on the plant species under evaluation. Moreover, photosynthetic carbon assimilation is a complex mechanism involving not just the $\mathrm{CBC}$ but photorespiration and photosynthetic electron transport. 


\subsection{Can Increasing Photorespiration Increase Yield?}

The carboxylation reactions carried out by $\mathrm{R}$ as part of the $\mathrm{CB}$ cycle, incorporating $\mathrm{CO}_{2}$ into complex downstream products, is contending with a parallel competing reaction where $\mathrm{R}$ fixes $\mathrm{O}_{2}$ in place of $\mathrm{CO}_{2}$ (Figure 1). This reaction, known as photorespiration, accounts for approximately $25 \%$ of the reactions carried out by $\mathrm{R}$ and leads to the formation of a molecule of 3-phosphoglycerate (3PGA) and a molecule of 2-phosphoglycolate (2PG). The formation and recycling of 2PG comes at a cost, impacting on photosynthetic efficiency and therefore negatively impacting yield potential [1,48-55]. A number of previous studies have shown that a reduction in photorespiratory flux under high photorespiratory conditions (i.e., high temperature or water stress) results in an overall reduction in photosynthetic efficiency and $\mathrm{CO}_{2}$ assimilation [56-59]. In contrast, green tissue-specific overexpression of the glycine decarboxylase (GDC) H-protein or L-protein has been shown to increase vegetative biomass in Arabidopsis and tobacco [42,60-63]. It is believed that increasing photorespiration prevents the build-up of toxic photorespiratory intermediates (e.g., 2-PGA, glycolate, glyoxylate or glycine) [42,53,60,62,64-69]. For example, 2-PGA has been shown to inhibit triose-phosphate isomerase (TPI) in pea [53], phosphoribulokinase (PRK) in spinach [64] and SBPase in Arabidopsis [70]. Furthermore, Glyoxylate inhibits ribulose-bisphosphate carboxylase/oxygenase (R) activation [68,69,71]. The over-expression of GDC-H was also recently shown to increase photosynthetic electron transport rates in Arabidopsis [42].

\subsection{Enhancing Photosynthetic Electron Transport Increases Yield}

Photosynthetic electron transport chain (ETC) is a succession of complexes that moves electrons between photosystem I (PSI) and photosystem II (PSII), creating an electrochemical proton gradient needed for the synthesis of ATP (see [72] and references therein). Directly increasing photosynthetic electron transport by the expression of the algal (Porphyra yezoensis) cytochrome $c_{6}$ has also been shown to increase yields in Arabidopsis [73,74] (Figure 2). Cytochrome $c_{6}$ has been shown to replace plastocyanin (PC) as an electron carrier in cyanobacteria and green algae in response to copper deficiency [75]. Furthermore, in Arabidopsis, cyt $c_{6}$ has been shown to transfer electrons from the cytochrome (cyt) $b_{6} f$ complex to PSI in vivo and faster than the reported rates for the native PC [73].

Furthermore, over-expression of the RieskeFeS protein in Arabidopsis, a key protein in the cyt $b_{6} f$ complex, leads to a substantial increase in the rates of $\mathrm{CO}_{2}$ assimilation, contributing to up to a $72 \%$ increase in biomass and a 51\% increase in seed yield in the best line [76]. Using Chlorophyll fluorescent imaging and Dual-PAM measurements, these authors showed that the over-expression of RieskeFeS (and resulting increases in other proteins of the cyt $b_{6} f$ complex: cyt $b_{6}$, cyt $f$, LhcaI, PsaA, PsbA, PsbD; see Figure 2), resulted in an increase in the potential quantum yield of PSI and PSII [76].

More recently, the over-expression of RieskeFeS in the C4 species Setaria viridis resulted in better light conversion in PSI and PSII with a $10 \%$ increase in complex content corresponding to a $10 \%$ increase in carbon assimilation [77]. Taken together, these data have suggested that the electron transport chain is also a limiting step in photosynthesis. Support for this came from antisense studies that have previously demonstrated that reductions in RieskeFeS protein levels result in decreases in photosynthetic electron transport and reduction in biomass and seed yield [78-84].

Other studies have looked at the over-expression of ferrodoxin (Fd), one of the final acceptors of electrons in the transport chain (Figure 2). Increasing the capacity for ferrodoxin to receive electrons would increase the capacity for photochemical quenching. However, constitutive OE of ferrodoxin led to no increase in photosynthetic efficiency in tobacco and no change to biomass yield was observed [85]. Furthermore, constitutive over-expression of ferrodoxin NADP reductase (FNR) in tobacco, the enzyme enabling the transfer of electrons from ferrodoxin to NADP+ (Figure 2) also led to no increase in photosynthetic efficiency or biomass yield [86]. More recently, constitutive OE of a plant ferrodoxin-like protein (PFLP), cloned from sweet peppers, in rice resulted in significantly higher electron transport rates, and up to a 1.3-fold increase in the rates of photosynthesis [87]. Transgenic plants showed a $28 \%$ increase 1000-grain weight and an increase in tiller number per plant. Moreover, transgenic plants had 
a higher fructose, glucose, sucrose and starch contents compared to controls [87]. Furthermore, OE of PFLP resulted in a 2- to 4 -fold increase in the transcript levels of CBC enzymes FBPase, SBPase (Figure 1), adenosine diphosphate glucose pyrophosphorylase (AGPase) and sucrose phosphate synthase (SPS) and a corresponding increase in protein levels.

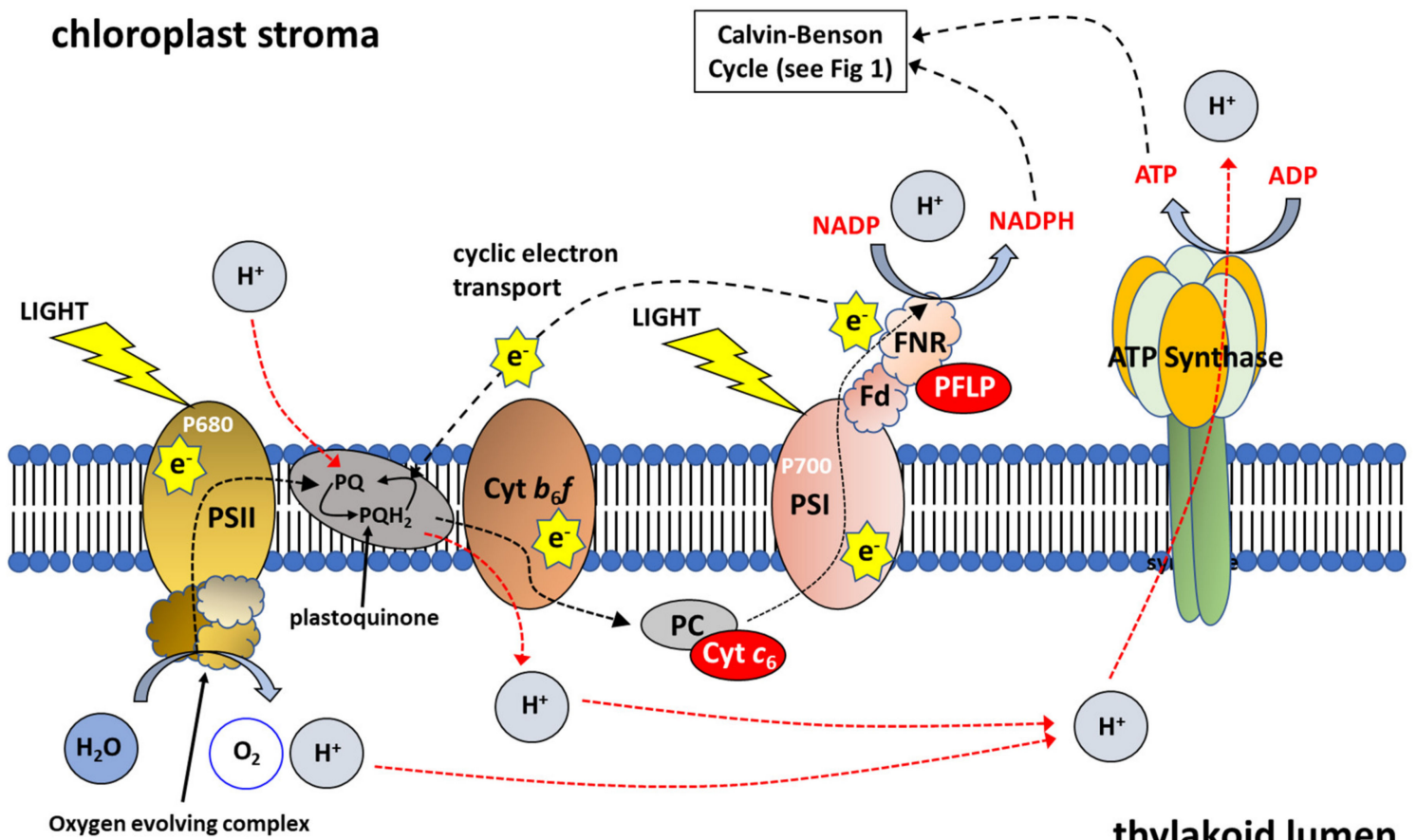

Figure 2. Schematic Representation of Photosynthetic Electron Transport. Photosystem I (PSI), Photosystem II (PSII), Cytochrome b6f complex (Cyt $\left.b_{6} f\right)$, plastocyanin (PC), Ferredoxin (Fd) and ferredoxin-NADP reductase (FNR). Cytochrome $c_{6}\left(\mathrm{Cyt} c_{6}\right)$ transfers electrons from the Cyt $b_{6} f$ complex to PSI at a faster rate than observed for PC; plant ferrodoxin-like protein (PFLP) (Adapted from [23]).

\subsection{Multi-Targeted Approaches to Improve Photosynthetic Efficiency Can Have a Synergistic Effect}

Studies combining the over-expression of CBC proteins, photorespiratory proteins and proteins increasing photosynthetic electron transport have recently been carried out $[41,42,88]$. These results suggest that manipulating multiple targets can have a synergistic effect on biomass accumulation and that this synergistic effect is target and plant specific (Table 1). These data also demonstrate that targeting different pathways should also be explored. Dual targeting of CBC and photorespiration or $\mathrm{CBC}$ and electron transport have resulted in significant increases in yield in both controlled and field experiments (see Table 1). However, targeting of ETC currently focuses on single target manipulation (RieskeFeS, cyt $c_{6}$ or ferrodoxin: Figure 2). An approach to increasing electron transport by simultaneously targeting the cyt $b_{6} f$ complex, plastocyanin and ferrodoxin has further potential to either increase electron transport or maintain consistent elevated rates under a range of environmental conditions. Targeting CBC, ETC and Photorespiration concurrently is the next logical step to improve $\mathrm{CO}_{2}$ assimilation rates in crops.

Improving photosynthesis to increase yields is currently focused on leaf tissue, however little consideration has been given to the impact of non-foliar green tissues photosynthesis on yields. Recently, Simkin et al. [89] summarized the current literature to evaluate the contribution of different photosynthetically active organs to yield and quality of fruits and grain. Photosynthesis has been shown to occur in in petioles and stems [90], seeds [91], fruit [92-95] and wheat ears [96] as well as in the husks of corn [97] and it has been suggested that photosynthesis in these tissues could provide an alternative sources of photoassimilates essential for optimal yields and quality. Simkin et al. [89] also 
showed that transgenic wheat with constitutively increased SBPase activity revealed increased gross photosynthesis in the ears in transgenic lines compared to wild type. These authors further proposed that increases in yield observed in SBPase OE wheat may not be solely due to foliar expression, and that increased activity in the ears may have contributed to the reported $40 \%$ increase in grain yield in these plants [89]. This work has highlighted the potential benefits of manipulating non-foliar photosynthesis (i.e., in fruit, wheat ears, seeds and embryos) and their potential impact on quality and nutritional value.

Table 1. Summary of the cumulative impacts of multiple transgenes manipulating Calvin-Benson Cycle, Photorespiration, $\mathrm{CO}_{2}$ transport and Photosynthetic Electron Transport and their biological outcomes (Arabidopsis; LL; Low Light $=130 \mathrm{~mol} / \mathrm{m}^{-2} / \mathrm{s}^{-1}$ and HL; High Light $=390 \mathrm{~mol} / \mathrm{m}^{-2} / \mathrm{s}^{-1}$. Tobacco LL $\left.=200-350 \mathrm{~mol} / \mathrm{m}^{-2} / \mathrm{s}^{-1} ; \mathrm{HL}=600-1400 \mathrm{~mol} / \mathrm{m}^{-2} / \mathrm{s}^{-1}\right)$. Sedoheptulose-1,7-bisphosphatase (SBPase); fructose-1,6-bisphosphate aldolase (Ald); Bifunctional FB/SBPase (FS Bif); Glycine decarboxylase $\mathrm{H}$ protein $(\mathrm{GDCH})$ Cytochrome $c_{6}\left(\mathrm{Cyt} c_{6}\right)$; inorganic carbon transporter B (ictB) (see Figures 1 and 2).

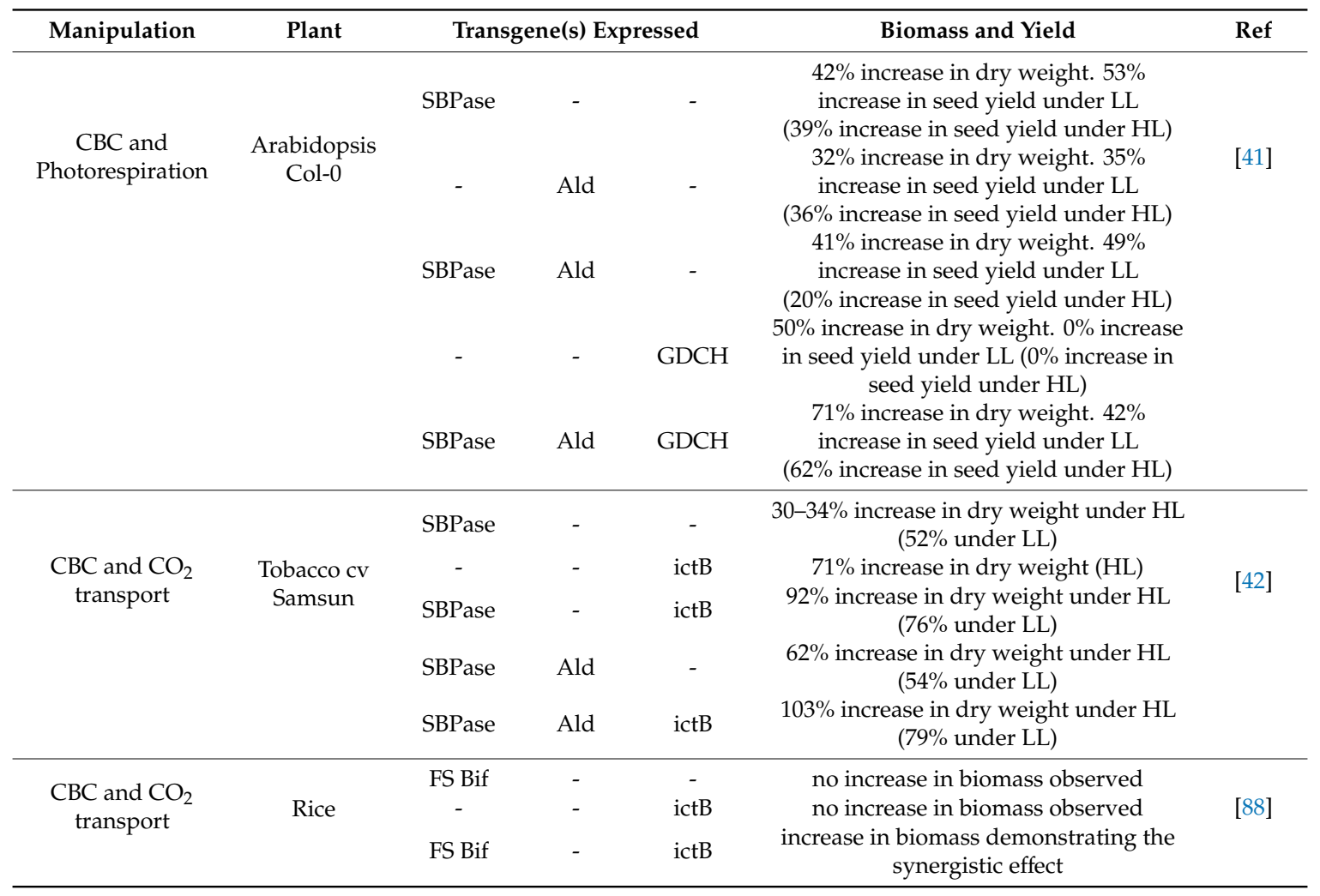

Therefore, a multi-gene, multi-tissue targeting approach to improving photosynthetic efficiencies in crops may increase the availability of photoassimilates for growth, dependent on (i) the role of non-foliar tissue in photosynthetic assimilation and (ii) the species-species interaction of multiple transgenes on cumulative yield. These areas of exploitation thus require additional research to explore the contribution of non-foliar photosynthesis to yield and quality. Furthermore, as photosynthesis provides the building blocks for a number of vitamin precursors (Figure 1), manipulating photosynthesis offers the potential to modify the nutritional quality of fruit, grain or leaves (see Section 2.5).

\subsection{Increasing Photosynthetic Carbon Availability Can Positively Affect Vitamin Content (Biofortification)}

More recently, it has been reported that elevated $\left[\mathrm{CO}_{2}\right]$ has a positive effect on Vitamin $\mathrm{C}$ (see Section 3.4) accumulation in sour orange (Citrus aurantium) [98], strawberry (Fragaria $\times$ ananassa) [99], tomato [100], and carrots (Daucus carota) [101], providing evidence that enhancing $\mathrm{CO}_{2}$ assimilation rates through genetic manipulation or growing crops in high $\left[\mathrm{CO}_{2}\right]$ environments (currently used for tomato and strawberry) could potentially impact on Vitamin C content (see Section 3.4). Furthermore, 
attempts to increase Vitamin C content in plant tissues have had additional outcomes. Vitamin C has been shown to play a role in photo-protection and increasing Vitamin $C$ content in green-tissue has been shown to enhance photosynthetic performance and growth [102].

\section{Biofortification}

Biofortification is the process of increasing and concentrating the available micronutrient in crop plants through breeding or genetic engineering. Biofortified crops can be used to improve human nutrition and have the potential to provide the micronutrients required in remote communities with low diet variability. Current approaches to artificially supplement the micronutrient requirements of large populations, either through adding it to food after processing or in pill form, represent a significant and continual financial output. Breeding or genetically engineering can alleviate this need to provide dietary supplementation to large populations over an extended period of time. Nutritionally improved crops can be grown at no additional cost to the farmers and the initial research investment is small compared to the potential economic gains. It has been estimated that every dollar invested in the development of biofortified crops could result is a financial saving of up to \$17 [103].

\subsection{Increasing Pro-Vitamin A Content in Planta}

Vitamin A is derived from C40 tetraterpenoids (isoprenoids; Figure 1 [104,105]) containing at least one $\beta$-ionone ring (see Figure 3A). $\beta$-carotene, $\beta$-cryptoxanthin and $\alpha$-carotene are found in green vegetables and fruit. These three carotenoids represent the most common precursors of vitamin $A$ in the human diet and $\beta$-carotene is one of the most abundant carotenoids in nature where it plays a key photo-protective role in plants $[106,107]$. These pro-vitamin A carotenoids are converted into retinal either enzymatically by the $\beta$-carotene cleavage oxygenase $I$, first cloned from fruit flies in 2001 [108] and later from chicken [109] and humans [110] or through non-enzymatic degradation (photodegradation, thermal degradation or oxidation). $\beta$-carotene can result in the formation of two molecules of vitamin A and is found in all green leafy plant tissues (i.e., lettuce (Lactuca sativa) [111]) and at high levels in some fruits (apricots (Prunus armeniaca) [112])) and peach (P. persica) [113]) and vegetables (i.e., carrot (Daucus carota) $[114,115])$ ).

Vitamin A, also known as retinol, is an essential micronutrient playing important roles in growth and development, vision [116] and the immune system [117]. Without Vitamin A, mammals are incapable of growth, reproduction or of fighting off disease [118]. In the form of retinal (Figure 3B), vitamin A combines with opsin (protein) to form rhodopsin, a light absorbing molecule required for low light and color vision. Retinal can be converted in a reversible reaction to retinol in the small intestine, which functions primarily as a storage form. In the form of retinoic acid, vitamin A functions as an essential hormone-like growth factor for epithelial cells (Figure 3B).

Vitamin A deficiency affects more than a third of all preschool children around the world (and a large proportion of pregnant women) and leads to night blindness and increases the risk of miscarriage and death to pregnant women $[119,120]$. Most people suffering from a Vitamin A deficiency show no clinical symptoms and people are often unaware of that deficiency in a phenomenon often called 'hidden hunger' [121]. Vitamin A deficiencies are more common in populations where staple food crops such as cereals and tubers are relied upon for the vast majority of calories consumed, because these food sources are poor sources of provitamin A carotenoids [121]. Crops such as wheat (Triticum aestivum), rice (Oryza sativa), cassava (Manihot esculenta) and potato (Solanum tuberosum), which make up a large part of the diets of poorer communities, contain no significant levels of carotenoids or carotenoid derived products. 


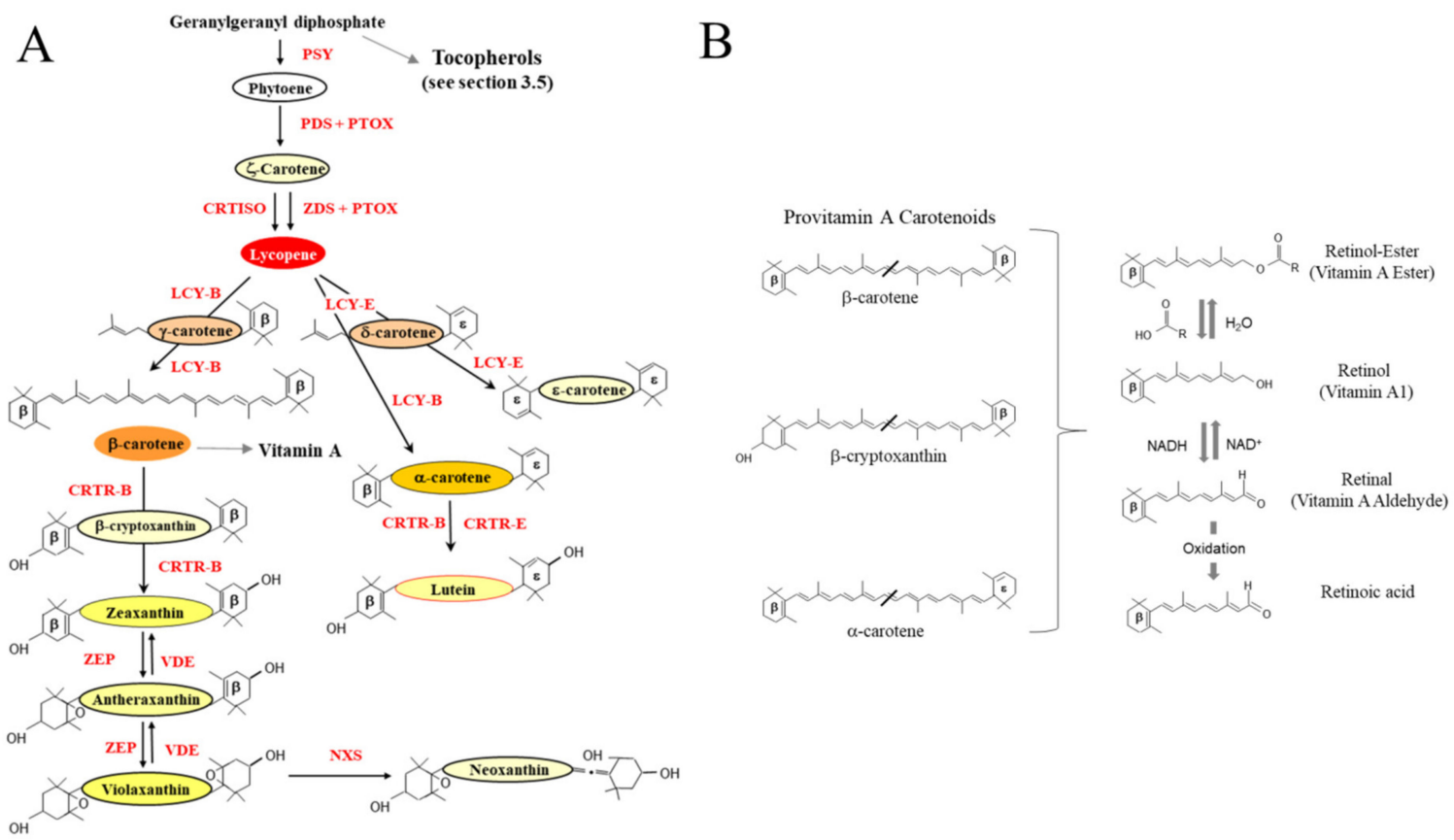

Figure 3. Carotenoid and pro-vitamin A synthesis in planta. (A) Overview of the biosynthesis of isoprenoids in plastids. PSY: Phytoene synthase. PDS: phytoene desaturase. ZDS: $\zeta$-carotene desaturase. PTOX: plastid terminal oxidase. CRTISO: carotenoid isomerase. LCY-B: lycopene $\beta$-cyclase. LCY-E: lycopene $\varepsilon$-cyclase. CRTR-B: $\beta$-carotene hydroxylase. CRTR_E: $\varepsilon$-carotene hydroxylase. ZEP: zeaxanthin epoxidase. VDE: violaxanthin de-epoxidase. NXS: neoxanthin synthase (Adapted from $[104,122,123])$. (B) Carbon structure of the three key provitamin A carotenoids. Beta rings are indicated $(\beta)$. Retinal is formed either by the enzymatic oxidative cleavage or non-enzymatic degradation of carotenoid precursors (Provitamin A carotenoids). The retinol-ester is primarily consumed from foods of animal origin and is converted to retinol (key storage form) in the small intestine. Retinal can be oxidized to retinoic acid, an essential hormone-like growth factor required by epithelial cells.

Increasing the pro-vitamin A content of these staple crops through genetic engineering of carotenoid biosynthesis has resulted in high carotenoid varieties of tomato (Solanum lycopersicum) [124-126], maize (Zea mays) [127,128], wheat [129], canola (Brassica napus) [130], potato (Solanum tuberosum) [131-133], flaxseed (Linum usitatissimum) [134,135], cassava (Manihot esculenta) [132] and Sorghum [136,137] (Table 2). Early efforts to increase pro-vitamin A content in rice (Oryza sativa) resulted in the generation of the $\beta$-carotene enriched "golden rice" $[138,139]$, firstly over-expressing the rate limiting enzyme phytoene synthase (PSY) and subsequently by over-expressing multiple enzymatic steps [139]. Paine et al. [139] also demonstrated that the origin of the PSY was critical to maximising carotenoid accumulation in rice endosperm (Table 2).

Furthermore, enhancing carotenoid deposition by manipulating carotenoid storage sinks has also shown some promise. For example, the over-expression of fibrillin or the Orange Carotenoid protein has been shown to result in a significant increase in carotenoid content in tomato fruit and tubers [126,140-144]. Table 2 further shows the importance of taking a multigene approach to increasing pro-vitamin A content in crops. 
Table 2. Summary of the cumulative impacts of multiple transgenes manipulating the accumulation of pro-vitamin A carotenoids (See Figure 3A). 1-Deoxy-D-xylulose-5-phosphate synthase (Dxs); phytoene synthase (Psy) phytoene desaturase (Pds); lycopene $\beta$-cyclase (Lyc); Orange carotenoid protein (Or); Fibrillin (Fib); Hordeum vulgare homogentisic acid geranylgeranyl transferase (HGGT); Erwinia uredovora phytoene synthase (crtB); Erwinia uredovora phytoene desaturase (crtL); Pantoea ananatis carotene desaturase (CrtI); E. uredovora lycopene $\beta$-cyclase (CrtY); Escherichia coli phosphomannose isomerase (PMI); E. coli 1-Deoxy-D-xylulose-5-phosphate synthase (DXS).

\begin{tabular}{|c|c|c|c|c|c|}
\hline Plant & Trans & ene(s) Exp & ssed & Metabolite Analysis & Ref \\
\hline \multirow[t]{5}{*}{ Tomato fruit } & crtB & - & - & $\begin{array}{l}\text { phytoene content increase (1.6-3.1-fold). Lycopene (1.8-2.1-fold) } \\
\text { and } \beta \text {-carotene (1.6-2.7-fold) were increased }\end{array}$ & [125] \\
\hline & - & crtL & - & $\begin{array}{l}\beta \text {-carotene content increased about threefold, up to } 45 \% \text { of the } \\
\text { total carotenoid content }\end{array}$ & {$[124]$} \\
\hline & - & - & SlLyc & $\begin{array}{l}\text { Increase in total carotenoids (2.3-fold). } \beta \text {-carotene increased } \\
(11.8 \text {-fold) and Lycopene decrease (10-fold) }\end{array}$ & [145] \\
\hline & - & - & AtOr & $\begin{array}{c}\text { Increases in Lycopene (1.6-fold), } \alpha \text {-carotene } 2.6 \text {-fold) and } \\
\beta \text {-carotene (2.7-fold) }\end{array}$ & [142] \\
\hline & - & - & CaFib & Increases in Lycopene (2.2-fold) and $\beta$-carotene (1.6-fold) & {$[126]$} \\
\hline \multirow{3}{*}{$\begin{array}{l}\text { Cassava } \\
\text { tubers }\end{array}$} & $\operatorname{crtB}$ & - & - & $\begin{array}{l}\sim 15 \text {-fold increases in carotenoids (as all-trans- } \beta \text {-carotene) } \\
\quad(40-60 \mu \mathrm{g} / \mathrm{g} \text { DW compared to CN 0.5-1 } \mu \mathrm{g} / \mathrm{g} \mathrm{DW})\end{array}$ & \multirow{3}{*}[132]{} \\
\hline & crtB & AtDxs & - & $\begin{array}{l}20 \text { - to } 30 \text {-fold increases in carotenoids (as all-trans- } \beta \text {-carotene) } \\
\qquad(25 \mu \mathrm{g} / \mathrm{g} \text { DW) compared to CN } 0.5-1 \mu \mathrm{g} / \mathrm{g} \mathrm{DW})\end{array}$ & \\
\hline & - & - & BoOr & $\begin{array}{l}\sim 2 \text {-fold increases in carotenoids (as all-trans- } \beta \text {-carotene) } \\
\quad(3-4 \mu \mathrm{g} / \mathrm{g} \mathrm{DW}) \text { compared to CN } 0.5-1 \mu \mathrm{g} / \mathrm{g} \mathrm{DW})\end{array}$ & \\
\hline \multirow{5}{*}{ Potato tubers } & - & DXS & - & $\begin{array}{l}\text { 2-fold increase in total carotenoids and 6- to 7-fold increase in } \\
\text { phytoene }\end{array}$ & [146] \\
\hline & crtB & - & - & $\begin{array}{c}\text { Carotenoid levels reached } 35 \mu \mathrm{g} / \mathrm{g} \text {. } \beta \text {-carotene levels in the } \\
\text { transgenic tubers reached } \sim 11 \mu \mathrm{g} / \mathrm{g} \mathrm{DW}\end{array}$ & [133] \\
\hline & crtB & AtDxs & - & $37-109 \mu \mathrm{g} / \mathrm{g}$ DW total carotenoids $(\mathrm{CN} 8 \mu \mathrm{g} / \mathrm{g})$ & [132] \\
\hline & crtB & crtL & $\operatorname{crtY}$ & $\begin{array}{c}\text { 20-fold increase (to } 114 \mu \mathrm{g} / \mathrm{g} \mathrm{DW}) \text { with } \beta \text {-carotene } 3600 \text {-fold } \\
\text { higher }(47 \mu \mathrm{g} / \mathrm{g} \mathrm{DW})\end{array}$ & [131] \\
\hline & - & - & BoOr & $\begin{array}{l}\text { The total carotenoid contents were 6-old higher than CN. } \\
\text { Increasing from } \sim 4 \mu \mathrm{g} / \mathrm{g} \text { DW to } \sim 22 \mu \mathrm{g} / \mathrm{g} \text { DW }\end{array}$ & {$[140]$} \\
\hline Canola seed & $\operatorname{crtB}$ & - & - & $\begin{array}{l}\text { 50-fold increase in carotenoids with } \alpha \text {-and } \beta \text {-carotene. Lutein, } \\
\text { the predominant carotenoid in } \mathrm{CN} \text { seeds remained at similar } \\
\text { levels in transgenic seeds }\end{array}$ & [130] \\
\hline Soybean & crtB & - & - & $\begin{array}{l}\text { Accumulate } 845 \mu \mathrm{g} / \mathrm{g} \text { DW of } \beta \text { carotene. An increase of } \\
1500 \text {-fold compared to CN }\end{array}$ & [147] \\
\hline Wheat & ZmPsy & $\operatorname{ctrI}$ & - & $\begin{array}{l}\text { Increase } \beta \text {-carotene from } 0.81 \mu \mathrm{g} / \mathrm{g} \mathrm{DW} \text { to } 2.3-4.9 \mu \mathrm{g} / \mathrm{g} \mathrm{DW} \text { in } \\
\text { the best lines }\end{array}$ & [129] \\
\hline \multirow[t]{3}{*}{$\begin{array}{l}\text { Cavendish } \\
\text { Banana }\end{array}$} & MtPsy & - & - & $\begin{array}{l}\text { Increase in } \beta \text {-carotene content from } 3.1 \mu \mathrm{g} / \mathrm{g} \mathrm{DW} \text { in fully ripe } \\
\text { fruit to up to } 8.3 \mu \mathrm{g} / \mathrm{g} \mathrm{DW} \text {. }\end{array}$ & \multirow[t]{3}{*}{ [148] } \\
\hline & ZmPsy & - & - & $\begin{array}{c}\text { Increase in } \beta \text {-carotene content from } 3.1 \mu \mathrm{g} / \mathrm{g} \text { DW in fully ripe } \\
\text { fruit to up to } 9.0 \mu \mathrm{g} / \mathrm{g} \text { DW. }\end{array}$ & \\
\hline & ZmPsy & $\operatorname{ctrI}$ & - & $\begin{array}{l}\text { Increase in } \beta \text {-carotene content from } 3.1 \mu \mathrm{g} / \mathrm{g} \mathrm{DW} \text { in fully ripe } \\
\text { fruit to up to } 13.2 \mu \mathrm{g} / \mathrm{g} \mathrm{DW} \text {. }\end{array}$ & \\
\hline \multirow[t]{2}{*}{ Maize } & ZmPsy & $\operatorname{ctrI}$ & - & $\begin{array}{l}\text { Increase } \beta \text {-carotene from } 0.35 \mu \mathrm{g} / \mathrm{g} \mathrm{DW} \text { to } 15-59 \mu \mathrm{g} / \mathrm{g} \mathrm{DW} \text { in } \\
\text { the best lines. Up to } 100 \text {-fold increase in total carotenoids (see } \\
\text { Section 3.6) }\end{array}$ & [149] \\
\hline & crtB & $\operatorname{ctrI}$ & - & $\begin{array}{c}\text { Increase } \beta \text {-carotene from } 0.39 \mu \mathrm{g} / \mathrm{g} \text { DW to } 9.8 \mu \mathrm{g} / \mathrm{g} D W \text { in the } \\
\text { best line }\end{array}$ & [127] \\
\hline \multirow{7}{*}{ Rice } & NpPsy & $\operatorname{crtI}$ & - & $\beta$-carotene, + small amounts of lutein and zeaxanthin & [138] \\
\hline & NpPsy & $\operatorname{crtI}$ & NpLyc & $1.6 \mu \mathrm{g} / \mathrm{g}$ carotenoid in the endosperm & \multirow{6}{*}[139]{} \\
\hline & NpPsy & crtI & - & $0.8-1.2 \mu \mathrm{g} / \mathrm{g}$ (up to $68 \% \beta$-carotene) & \\
\hline & SiPsy & crtI & - & $0.9-1.2 \mu \mathrm{g} / \mathrm{g}$ (up to $68 \% \beta$-carotene) & \\
\hline & CaPsy & crtI & - & $1.1-4.7 \mu \mathrm{g} / \mathrm{g}$ (up to $80 \% \beta$-carotene) & \\
\hline & ZmPsy & crtI & - & Up to $14.5 \mu \mathrm{g} / \mathrm{g}$ (up to $89 \% \beta$-carotene) & \\
\hline & OsPsy & crtI & - & Up to $18.4 \mu \mathrm{g} / \mathrm{g}$ (up to $86 \% \beta$-carotene) & \\
\hline \multirow[t]{2}{*}{ Sorghum } & AtDxs & ZmPsy & $\begin{array}{l}\text { ctrI, } \\
\text { PMI }\end{array}$ & $\begin{array}{c}\beta \text {-carotene levels ranged from } 2.5 \text { to } 9.1 \mu \mathrm{g} / \mathrm{g} \text { DW in the mature } \\
\text { seeds compared to CN } 0.5 \mu \mathrm{g} / \mathrm{g} \text { DW }(+10 \text {-fold })\end{array}$ & \multirow[t]{2}{*}{ [136] } \\
\hline & HGGTAt & xzmPsy, & $\begin{array}{l}\text { ctrI, } \\
\text { PMI }\end{array}$ & $\begin{array}{c}\text { all-trans } \beta \text {-carotene levels ranged from } 7.3 \text { to } 12.3 \mu \mathrm{g} / \mathrm{g} \mathrm{DW} \text { in } \\
\text { the mature seeds compared to CN } 0.5 \mu \mathrm{g} / \mathrm{g} \text { DW }(\sim 19 \text {-fold } \\
\text { increase })+1.8 \text {-fold increase in } \alpha \text {-tocopherol }\end{array}$ & \\
\hline
\end{tabular}

Oryza sativ (Os); Solanum lycopersicum (Sl); Capsicum annum (Ca); Brassica oleracea (Bo); Arabidopsis thaliana (At); Zea mays (Zm); Narcissus pseudonarcissus (Np); Hordeum vulgare (Hv); Musa troglodytarum $x$ acuminate (Mt). $\mathrm{CN}=$ control. 
It should be noted that increasing carotenoid content to improve pro-vitamin A content has potential drawbacks. Firstly, a 50-fold increase in carotenoids in canola results in (i) an $80 \%$ reduction in chlorophyll levels in seeds and (ii) an average 50\% decrease in tocopherol levels [130]. The decrease in chlorophyll potentially affects the contribution on non-foliar photosynthesis (see Section 2.5). In canola, seed photosynthesis has been shown to play a role in the accumulation of important storage lipids $[150,151]$ and secondly tocopherol is a required nutrient in human diets (see Section 3.5). The reductions in tocopherol have been addressed in Sorghum, where carotenoid biosynthetic genes were over-expressed along with homogentisic acid geranylgeranyl transferase (HGGT), which catalyses the committed step of tocotrienol biosynthesis has previously been shown to enhance total vitamin E antioxidants (see Section 3.5) (tocotrienols plus tocopherols) content by 10- to 15-fold [152]. Furthermore, in cassava and potato, increasing content resulted in a $25 \%$ decrease in the dry matter content of the tubers, and a decrease in starch content, whist sucrose, glucose, total fatty acid, triacylglycerols increased [132].

Biofortified maize engineered to accumulate pro-vitamin A has shown to be effective at significantly increasing the total body stores of vitamin A in 5- to 7-year-old children [153]. Consumption of $\beta$-carotene fortified maize has been proven to be as effective at controlling vitamin A deficiency as taking supplements [153] and has also been shown to improve visual function in children with a vitamin A deficiency [154]. Although these results clearly show the benefits of increasing pro-vitamin A content in staples, these increases come with metabolic and nutrient changes that merit more investigation.

\subsection{Genetic Manipulation of Folate (Vitamin $B_{9}$ ) Accumulation}

Folate is synthesized by plants and micro-organisms, is water soluble and is an essential micronutrient. Folates consist of three parts, a pteridine, $\mathrm{p}$ Aminobenzoate (PABA), and glutamate moieties (Figure 4A). In plants, folate biosynthesis is compartmentalized, with PABA synthesized in the plastid (derived from chorismate [from Shikimate pathway, Figure 1]) and pteridines synthesized from guanosine-50-triphosphate (GTP) in the cytosol. These two moieties are translocated into the mitochondria, where they are condensed to form dihydropteroate, which is then glutamylated (modified by reaction with glutamate (Glu)) to form folates (Figure 4B) $[155,156]$. In plants, folates play essential roles in photorespiration, and in the synthesis of chlorophyll, plastoquinone, tocopherol, making them essential for plant health and development [157].

It has been recommended that adults consume $400 \mathrm{mg}$ of folate from foods or dietary supplements daily with pregnant women needing as much as $600 \mathrm{mg}$ daily [158]. Folates are essential coenzymes and a folate deficiency during pregnancy can cause neural tube defects (NTDs) in infants (i.e., spina bifida and anencephaly) and megaloblastic anemia [159-161]. In adults, folate deficiency has been associated with an increased risk of cardiovascular and coronary diseases, some forms of cancers and a loss of cognitive function [162,163]. Unfortunately, many crops consumed specifically by at risk populations (poorer communities in developing countries), including wheat, potatoes, cassava, rice and maize, contain insufficient quantities of folate and are unable to meet daily requirements, especially where other types of food are limited. Currently, flour and cereal-grain products are fortified with folic acid to overcome the issues of folate deficiency within the population; however, this does not address the issues of folate deficiency in poorer communities. To overcome this, genetic engineering approaches have been applied to increase folate content in crops [164-166].

Over-expression (OE) of the GTP cyclohydrolase I (GCHI) (Figure 4B), the first committed step in the pteridine pathway [167], in Arabidopsis resulted in a $>1000$-fold increase in pterins and only a 2- to 4-fold increase in folates (Table 3) [166]. Similar results were also observed following Seed-specific over-expression of GCHI in common Mexican bean [168]. These results were supported by similar work carried out by Diaz de la Gaza [164] who demonstrated that the OE of GCHI in tomato fruit resulted in an up to 140-fold increase in pterins and increased fruit folate content by an average of 2-fold [164]. In tomato fruit, OE of GCHI was also shown to result in the depletion of the chloroplast synthesized PABA, which suggested that PABA represents a further limiting step in folate biosynthesis 
in transgenic tomato fruit (Table 3). However, this depletion in PABA is in contrast with an increase observed following the OE of GCHI in Mexican bean [168]. These authors demonstrated that feeding fruit PABA though the fruit stalk could increase folate by up to 10-fold [164].

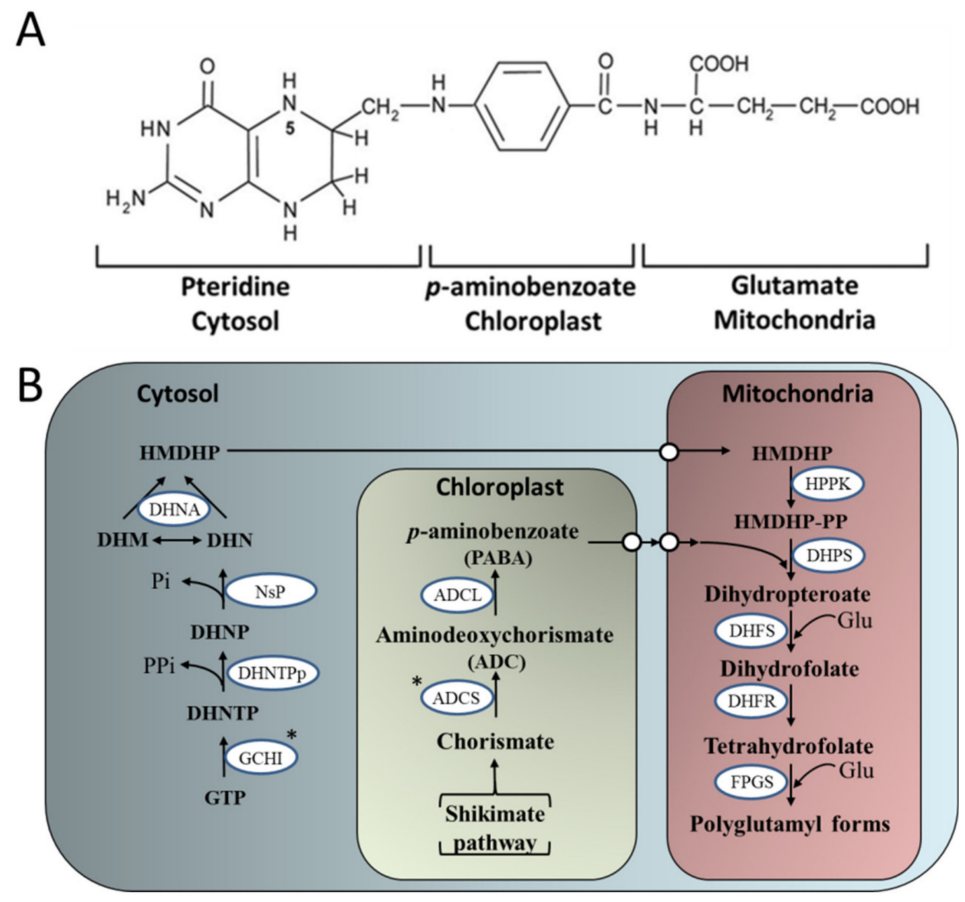

Figure 4. The plant folate biosynthesis pathway. (A) The chemical structure of monoglutamyl tetrahydrofolate (B) The pteridine pathway leading to hydroxymethyldihydropterin (HMDHP) in the cytosol; the pathway leading to p-aminobenzoate in the plastid, and condensation steps localized in the mitochondria are shown. DHN, dihydroneopterin; -P, monophosphate; -PP, pyrophosphate; -PPP, triphosphate; DHM, dihydromonapterin; Glu, glutamate; ADCS, aminodeoxychorismate synthase; ADCL, aminodeoxychorismate lyase; GCHI, GTP cyclohydrolase I; DHNTPp, dihydroneopterin triphosphate pyrophosphatase; NsP, non-specific phosphatase; DHNA, dihydroneopterin aldolase; HPPK, hydroxymethyldihydropterin pyrophosphokinase; DHPS, dihydropteroate synthase; DHFS, dihydrofolate synthase; DHFR, dihydrofolate reductase; FPGS, folylpolyglutamate synthetase. White circles represent points of substrate transport. *targeted enzymes for over-expression (Adapted from $[155,156])$.

A further attempt to increase fruit folate content came from the OE of the plastid localized aminodeoxychorismate synthase (ADCS) (Figure 4B), resulting in an up to 19-fold increase in PABA levels in ripe fruit. However, the OE of ADCS did not lead to an accumulation of folate and no differences could be observed between OE lines and controls (Table 3) [165]. However, these same authors demonstrated that when ADCS-OE lines were crossed with GCHI-OE lines, these double ADCS/GCHI transgenic lines accumulated pterins, PABA and folate in red ripe fruit. Work in other species has also demonstrated that increasing folate concentration by metabolic engineering remains an important direction to produce healthier fortified crops including staple crops consumed in developing countries (Table 3).

Work carried out by Dong et al. [169] in rice has shown that the manipulation of other folate biosynthetic genes, individually or in combination, can also lead to small increases in folate. This potential opens the door to a multigene approach to increasing folate concentration in a variety of foods. Recently, the bioavailability of metabolically engineered folate-biofortified rice was demonstrated in rats [170]. Studies evaluating this cost-effective approach to folate supplementation in China [171] have suggested that folate-biofortified crops could be invaluable in addressing the incidence of folate deficiency in whole populations [172]. 
Table 3. Summary of the cumulative impacts of multiple transgenes manipulating folate metabolism. $\mathrm{NR}=$ not reported. $\mathrm{CN}=$ control. GTP cyclohydrolase I (GCHI); aminodeoxychorismate synthase (ADCS) (see Figure 4B).

\begin{tabular}{|c|c|c|c|c|c|c|}
\hline \multirow{2}{*}{ Plant } & \multirow{2}{*}{\multicolumn{2}{|c|}{$\begin{array}{l}\text { Transgene(s) } \\
\text { Expressed }\end{array}$}} & \multicolumn{3}{|c|}{ Metabolite Analysis } & \multirow{3}{*}{$\begin{array}{l}\text { Ref } \\
{[166]}\end{array}$} \\
\hline & & & \multirow{2}{*}{$\begin{array}{c}\text { Pterins } \\
1250 \text {-fold increase }\end{array}$} & \multirow{2}{*}{$\begin{array}{c}\text { PABA } \\
\text { NR }\end{array}$} & \multirow{2}{*}{$\begin{array}{c}\text { Folate } \\
\text { 2- to 4-fold increase. }\end{array}$} & \\
\hline Arabidopsis & GCHI & - & & & & \\
\hline $\begin{array}{l}\text { Mexican } \\
\text { Bean }\end{array}$ & GCHI & - & 150-fold increase & Increase & $\begin{array}{l}\text { Up to 3-fold increase in } \\
\text { desiccated beans }\end{array}$ & [168] \\
\hline Lettuce & GCHI & - & NR & NR & 2- to 8.5 -fold increase & [173] \\
\hline \multirow[t]{2}{*}{ Potato } & GCHI & & $\begin{array}{l}\text { Approx. 18-fold } \\
\text { increase }\end{array}$ & Decrease & Up to 2-fold increase & \multirow[t]{2}{*}{ [174] } \\
\hline & GCHI & ADCS & $\begin{array}{l}\text { Approx. 33-fold } \\
\text { increase }\end{array}$ & $>6$-fold increase & Up to 3-fold increase & \\
\hline \multirow{3}{*}{ Tomato Fruit } & GCHI & - & $\begin{array}{l}\text { 3- to } 140 \text {-fold } \\
\text { increase }\end{array}$ & $\begin{array}{l}\text { Severely } \\
\text { depleted }\end{array}$ & $\begin{array}{l}\text { average 2-fold increase } \\
\text { in ripe fruit }\end{array}$ & \multirow[t]{3}{*}[164,165]{} \\
\hline & - & ADCS & $\begin{array}{l}\text { No increase } \\
\text { observed }\end{array}$ & $\begin{array}{l}\text { Up to } 20 \text {-fold } \\
\text { increase }\end{array}$ & $\begin{array}{l}\text { No increase observed in } \\
\text { ripe fruit }\end{array}$ & \\
\hline & GCHI & ADCS & $\begin{array}{l}\text { Up to } 30 \text {-fold } \\
\text { increase }\end{array}$ & $\begin{array}{l}\text { Up to } 20 \text {-fold } \\
\text { increase }\end{array}$ & $\begin{array}{l}\text { Up to } 25 \text {-fold increase } \\
\text { in ripe fruit }\end{array}$ & \\
\hline \multirow{3}{*}{ Rice } & GCHI & - & 25-fold increase & NR & No increase observed & \multirow[t]{3}{*}{ [175] } \\
\hline & - & ADCS & NR & $\begin{array}{l}49 \text { times higher } \\
\text { than controls }\end{array}$ & $\begin{array}{c}6 \text { times lower than in } \\
\text { controls }\end{array}$ & \\
\hline & GCHI & ADCS & 4-fold increase & $\begin{array}{l}25 \text { times high } \\
\text { than control }\end{array}$ & $\begin{array}{l}\text { 15-100 times higher } \\
\text { than CN }\end{array}$ & \\
\hline Corn & \multicolumn{2}{|c|}{$\begin{array}{l}\text { E. coli folE encoding } \\
\text { GCHI }\end{array}$} & NR & NR & $\begin{array}{l}\sim \text { 2-fold increase (see } \\
\text { Section 3.6) }\end{array}$ & [149] \\
\hline
\end{tabular}

\subsection{Cobalamin (Vitamin $B_{12}$ )}

Cobalamin, the biologically active form of Vitamin $B_{12}\left(B_{12}\right)$, is part of the modified tetrapyrrole family that includes molecules such as chlorophyll and haem and is made exclusively by a small group of prokaryotes (bacteria and archaea) [176]. Some of these bacteria are found in the flora of ruminant mammals where they proliferate in the stomach and continue to form $B_{12}$. This source of $\mathrm{B}_{12}$ accumulates in animal product including meat, eggs, milk [177] and is the key dietary source of $\mathrm{B}_{12}$ in the population, which raises issues for those following a vegan diet requiring supplementation often in the form of fortified cereals, plant-based milks, nutritional yeast, tablets or intramuscular injection [178] in order to avoid serious health consequences. $B_{12}$ is absent from fruits and vegetables, although nori, an edible purple/green, contains a significant concentration of $B_{12}$ [177]. However, this source of $B_{12}$ is controversial due to the presence of high quantities of pseudovitamin $B_{12}$, which may not be bioavailable and is also an inactive analogue in human diets [177].

The recommended daily allowance of $B_{12}$ for adult men and women is 2.0-2.4 $\mu \mathrm{g} /$ day with $2.6 \mu \mathrm{g} /$ day for pregnant women. Vitamin $B_{12}$ is an essential nutrient for animals where it is a cofactor required for the synthesis of DNA and neurotransmitters as well as for fatty acid and amino acid metabolism. Even at levels slightly lower than normal, $\mathrm{B}_{12}$ deficiency can result in a range of symptoms including depression, loss of memory (reduced cognitive performance), fatigue, lethargy and headaches and in some people mania and psychosis [179,180]. Many of these symptoms are the result of pernicious anaemia, a lack of red blood cells, which can lead to additional symptoms including chest pain, numbness in the hands and feet, poor reflexes, smooth red tongue and a shortness of breath [181].

Cobalamin is the most structurally complex and largest vitamin containing a cobalt at its centre surrounded by four pyrrole rings (Figure 5) and its biosynthesis requires approx. 30 enzyme-mediated steps, including a number of oxygen-sensitive and highly labile intermediates that make its synthesis by eukaryotic cells highly challenging [182-184]. 


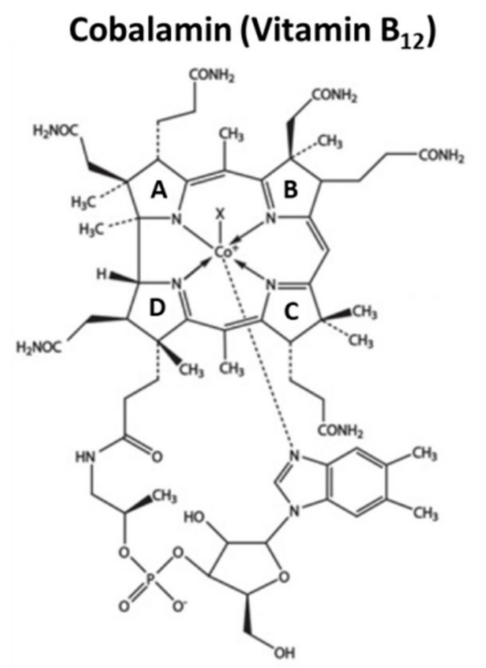

L-Ascorbic acid (Vitamin C)<smiles>O=C1OC(C(O)CO)C(O)=C1O</smiles>

Tocopherols (Vitamin E)

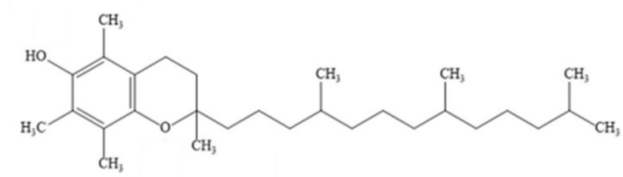

Figure 5. The chemical structures of Vitamin $\mathrm{B}_{12}$ (pyrrole rings are labelled A to D); Vitamin $\mathrm{C}$ and Vitamin E.

Due to the highly complex nature of $\mathrm{B}_{12}$, work to biofortify crops through genetic engineering has not yielded any significant results. However, biofortification of plants via feeding mechanisms has demonstrated that Lepidium sativum (garden cress) can take up $\mathrm{B}_{12}$ if grown in $\mathrm{B}_{12}$ enriched media, where it accumulates in the vacuole of the cotyledons, although the mechanism of uptake remains to be elucidated [185]. Furthermore, this method of biofortification requires the use of $B_{12}$ from other sources, such as bacterial fermentation cultures [186], and due to the ever-increasing price of vitamin $\mathrm{B}_{12}$ supplements this may not prove to be a viable option for biofortifying crops on a large scale unless a significant increase in vitamin $B_{12}$ manufacturing facilities is undertaken.

\subsection{L-ascorbic Acid (Vitamin C)}

Humans and some other primates have lost the ability to synthesize and store Vitamin $C$ and depend on dietary provision to cover their daily requirements of $75-90 \mathrm{mg}$. Vitamin C (Figure 5) is found in citrus fruits (oranges and lemons, etc.), grapefruit, mango, kiwifruit, broccoli, Brussels sprouts, tomatoes and a variety of berry fruits (strawberries, raspberries, blueberries, and cranberries) [187]. Vitamin $C$ is considered to be an essential nutrient required for the repair of connective tissues, collagen synthesis and the enzymatic production of some neurotransmitters. It is also important for correct immune system function and acts as an antioxidant. Previous research has suggested that Vitamin C can aid in the treatment of Alzheimer's, Huntington's and Parkinson's disease [188-190].

Under physiological $\mathrm{pH}$ conditions, Vitamin $\mathrm{C}$ exists almost exclusively as an ascorbate anion and functions as a co-factor for methylcytosine dioxygenases, enzymes involved in the demethylation of DNA [191]. Furthermore, Ascorbate serves as a cofactor for the Jumonji C-domain-containing histone demethylases required for the demethylation of histone [191]. These authors suggested that by participating in the demethylation of both DNA and histones, Vitamin C regulates epigenetic processes mediating the interaction between the environment and the genome. The impact of this interaction on human health has been reviewed [192]. In short, ascorbate deficiency potentially affects neonatal and postnatal developmental processes with long-term consequences for health through epigenetic dysregulation (i.e., cancer and neurodegeneration). Therefore, Vitamin C deficiency, in addition to the immediate consequences to the mother, could have long-term consequences for unborn children.

Vitamin $C$ is well tolerated and often taken as a supplement in tablet form, although in large doses Vitamin C can cause gastrointestinal discomfort, headache and result in insomnia. However, at high concentration it has been reported to play a role in the treatment of cancer, arteriosclerosis, and a number of other cardiovascular diseases [193-195]. In plants, Ascorbate metabolism is strongly 
linked with photosynthesis and has a well-documented role in photoprotection [196,197]. Ascorbate is a major antioxidant in chloroplast and has been reported to be an important cofactor for VDE activity in the carotenoid biosynthetic pathway (Figure 3A) [196]. When the absorption of light is beyond the plant's capacity, the excess energy needs to be dissipated. VDE converts violaxanthin (V) to zeaxanthin $(Z)$ in the daytime and zeaxanthin epoxidase (ZEP) converts Z back to V at night [198]. This inter-conversation, known as the xanthophyll cycle, is responsible for the dissipation of excess energy protecting photosynthetic membranes.

In plants, several different ascorbate biosynthesis pathways have been characterized (Figure 6). The Smirnoff-Wheeler pathway is the primary pathway in plants [199], however, three 'alternative' pathways have also been shown to lead to the production of ascorbate in planta. The myo-inositol pathway [200], L-gulose pathway [201,202], and D-galacturonate pathway [203,204]. However, work using Arabidopsis mutants suggests that these alternative pathways contribute a relatively small amount of ascorbate to the overall pool [205,206]. It has been suggested that manipulating these pathways to increase Vitamin C, to improve nutritional quality of horticultural crops, is a clear target of future research [207]. A number of reports have evaluated the over-expression or down-regulation of genes to determine their impacts on ascorbate levels (Table 4). The reports have focused either on the over-expression of biosynthesis and recycling enzymes or antisense suppression of ascorbate oxidase (enzyme 12: Figure 6 and Table 4).

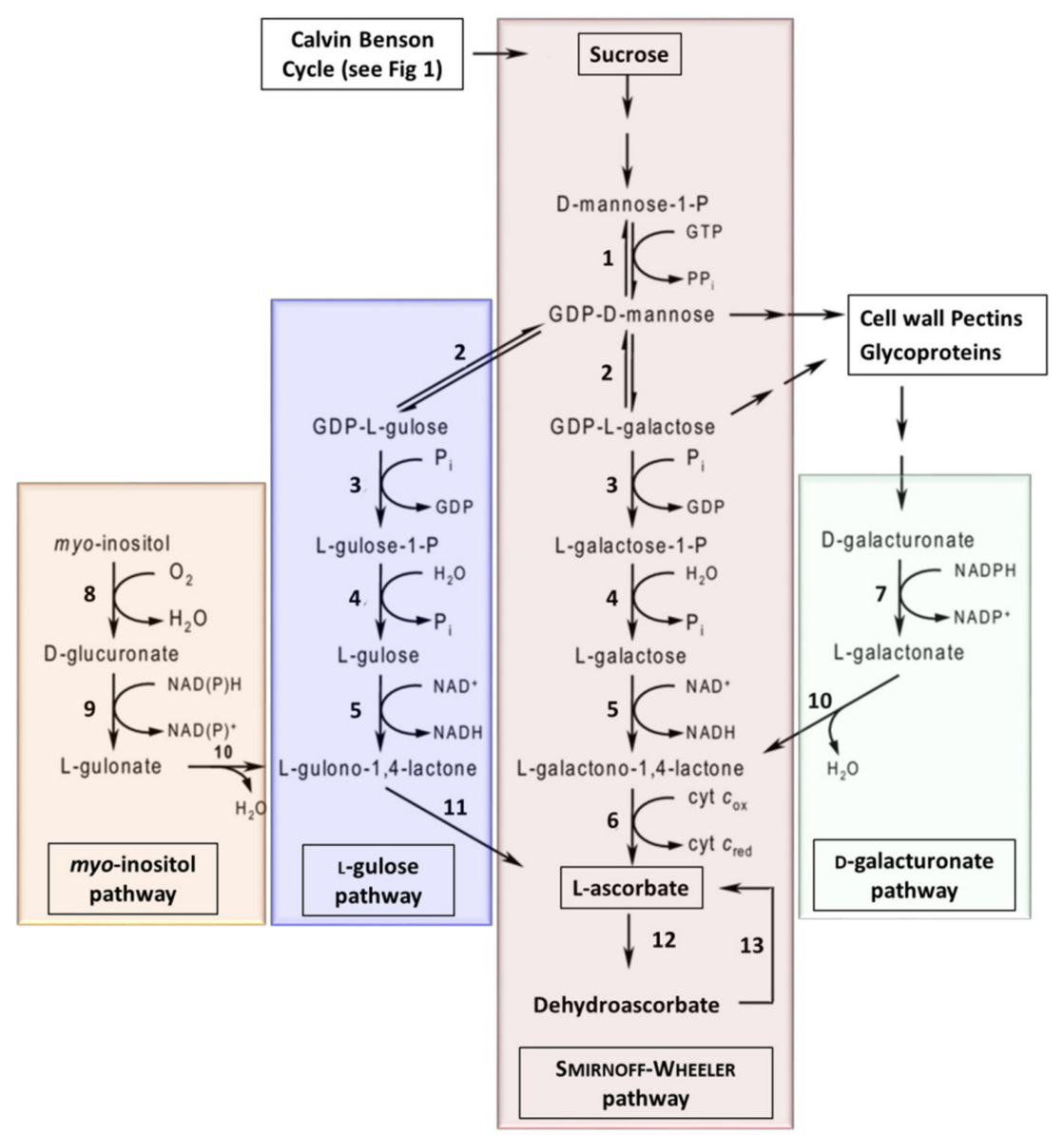

Figure 6. The biosynthetic pathways for vitamin C in plants. Enzymes: 1, GDP-D-Man pyrophosphorylase; 2, GDP-Man-3',5'-epimerase; 3, GDP-L-Gal phosphorylase (or transferase); 4, L-Gal 1-phosphate phosphatase; 5, L-Gal dehydrogenase; 6, L-GalL dehydrogenase; 7, D-galacturonate reductase; 8 , myo-inositol oxygenase; 9, D-glucuronate reductase; 10, aldonolactonase; 11, L-GulL oxidase (or dehydrogenase); 12, ascorbate oxidase; 13, dehydroascorbate reductase (adapted from $[149,208])$. 
Over-expression of genes GDP-Man-3',5'-epimerase ((GME) enzyme 2: Figure 6 and Table 4), a key step in both the Smirnoff-Wheeler and L-gulose pathways, was shown to result in a 1.2- to 1.6-fold increase in ascorbate in tomato fruit [209]. Furthermore, over-expression GDP-L-Gal phosphorylase ((GMP) enzyme 3: Figure 6 and Table 4), which is also active in both the Smirnoff-Wheeler and L-gulose pathways, was shown to result in a 2- to 6-fold increase in ascorbate levels in strawberry and tomato fruit, respectively, and an up to 3 -fold increase in ascorbate in potato tubers [210]. GDP-L-Gal phosphorylase ((GGP) enzyme 3: Figure 6) over-expression increased ascorbate content, suggesting that GGP is a key enzyme in the Smirnoff-Wheeler pathway [211]. Other studies have demonstrated that over-expression of GDP-D-Man pyrophosphorylase ((GMP) enzyme 1: Figure 6) also facilitates an increase in ascorbate [212].

Table 4. Summary of the impacts of manipulating ascorbate biosynthetic enzymes on ascorbate accumulation and ascorbate dehydroascorbate ratios (see Figure 6).

\begin{tabular}{|c|c|c|c|c|}
\hline Plant & Enzyme & Regulation & Metabolite Analysis & Ref \\
\hline Tomato & GDP-Man-3',5'-epimerase & Up & 1.2- to 1.6 -fold increase in fruit & [209] \\
\hline Arabidopsis & $\begin{array}{l}\text { GDP-L-Gal } \\
\text { phosphorylase }\end{array}$ & Up & Up to 4 -fold increase in best lines & [211] \\
\hline Tomato & $\begin{array}{l}\text { GDP-L-Gal } \\
\text { phosphorylase }\end{array}$ & Up & 3- to 6-fold increase in fruit ascorbate & [210] \\
\hline Strawberry & $\begin{array}{l}\text { GDP-L-Gal } \\
\text { phosphorylase }\end{array}$ & Up & 2-fold increase in tuber ascorbate & [210] \\
\hline Potato & $\begin{array}{l}\text { GDP-L-Gal } \\
\text { phosphorylase }\end{array}$ & Up & Up to 3-fold increase in fruit ascorbate & [210] \\
\hline Tobacco & ascorbate oxidase & Down & $\begin{array}{l}\text { 1.9-fold increase in ascorbate and increase } \\
\text { in the Ascorbate to DHA ratio }\end{array}$ & [213] \\
\hline Tobacco & ascorbate oxidase & Down & $\begin{array}{l}\text { No increase in the ascorbate pool but } \\
\text { increase in ratio of Ascorbate to DHA }\end{array}$ & [214] \\
\hline Tobacco & $\begin{array}{l}\text { dehydroascorbate } \\
\text { reductase }\end{array}$ & Up & $\begin{array}{l}\text { 2.2- to } 3.9 \text {-fold increase in ascorbate and } \\
\text { increase in the Ascorbate to DHA ratio }\end{array}$ & [215] \\
\hline Maize & $\begin{array}{l}\text { dehydroascorbate } \\
\text { reductase }\end{array}$ & Up & $\begin{array}{l}\text { 1.9-fold increase in ascorbate and increase } \\
\text { in the Ascorbate to DHA ratio }\end{array}$ & [215] \\
\hline Arabidopsis & D-glucuronate reductase & Up & 2- to 3-fold increase in ascorbate & [203] \\
\hline Potato & $\begin{array}{l}\text { D-galacturonate } \\
\text { reductase }\end{array}$ & Up & Up to 2-fold increase in tuber ascorbate & [216] \\
\hline Tobacco & L-gulonolactone oxidase & Up & 7-fold increase in ascorbate & [217] \\
\hline Lettuce & L-gulonolactone oxidase & Up & 4- to 7-fold increase in ascorbate & [217] \\
\hline Arabidopsis & L-gulonolactone oxidase & Up & $\sim 2.0$-fold increase in ascorbate & [218] \\
\hline Arabidopsis & myo-inositol oxygenase & Up & $\begin{array}{l}\text { 2- to 3-fold increase in the ascorbate content } \\
\text { of leaves compared with controls }\end{array}$ & [200] \\
\hline Corn & $\begin{array}{l}\text { dehydroascorbate } \\
\text { reductase }\end{array}$ & Up & $\begin{array}{l}\text { Up to 7.5-fold increase in ascorbate (see } \\
\text { Section 3.6) }\end{array}$ & [149] \\
\hline Tobacco & malate dehydrogenase & Down & 5.7-fold increase in ascorbate & [102] \\
\hline
\end{tabular}

In 2019, the over-expression of L-Gal dehydrogenase ((GDH) enzyme 5: Figure 6) or L-GalL dehydrogenase ((GLDH) enzyme 6: Figure 6) also led to small increases in ascorbate content in acerola fruits (Malpighia glabra), whilst the over-expression of GME had minimal effect on ascorbate levels [219]. These authors also demonstrated that the co-expression of GMP (enzyme 1) and GGP (enzyme 3) resulted in higher ascorbate levels compared to GMP or GGP alone [219]. Furthermore, co-overexpression of GMP (enzyme 1), GME (enzyme 2), and GGP (enzyme 3) significantly increased ascorbate contents compared to the dual expression of GMP and GGP [219]. These data suggest that expressing the three upstream enzymes in the Smirnoff-Wheeler pathway has a synergistic effect on ascorbate levels. In contrast, co-overexpression of GGP (enzyme 4), GDH (enzyme 5), and GLDH (enzyme 6) resulted in no differences in ascorbate [219]. 
A number of reports have also evaluated the over-expression of targets in the three 'alternative' ascorbate biosynthetic pathways. For example, the over-expression of L-gulonolactone oxidase (enzyme 11: Figure 6) results in a 2- to 7-fold increase in ascorbate levels [217,218]. Furthermore, over-expression of D-galacturonate reductase (enzyme 7: Figure 6) resulted in a 2- to 3-fold increase in ascorbate in Arabidopsis [203]. Finally, constitutive expression of myo-inositol oxygenase (enzyme 8: Figure 6), which catalyzes the oxidation of myo-inositol into D-glucuronate, resulted in a 2- to 3-fold increase in ascorbate (Table 4) [200].

Some horticultural crops, including tomato and strawberry, are commercially grown at elevated $\mathrm{CO}_{2}$ under glass. Elevated $\left[\mathrm{CO}_{2}\right]$ has previously been shown to cause an increase in ascorbate in sun-acclimated leaves of sour orange [220], and recent work by Wu et al. has shown that carrots grown under elevated $\left[\mathrm{CO}_{2}\right]$ accumulate Vitamin $\mathrm{C}$ due to changes in the expression levels of 12 biosynthetic genes [101]. Furthermore, elevated $\left[\mathrm{CO}_{2}\right]$ was also shown to result in increases in the expression of ascorbate-related genes and enzyme activities and a 1.09-3.91-fold increase in Vitamin $C$ in celery petioles [221]. These results suggest that enhancing photosynthesis (see Section 2) is a potential route to biofortify crops. However, it should be noted that growing barley at elevated $\left[\mathrm{CO}_{2}\right]$ resulted in a significant decrease in ascorbate [222], demonstrating species-species response differences to atmospheric $\mathrm{CO}_{2}$, which requires further study. For review, see [187]. Finally, down-regulating the activity of the mitochondrial malate dehydrogenase in transgenic tomato was shown to enhance photosynthesis, chloroplastic electron transport rates and $\mathrm{CO}_{2}$ assimilation, resulting in an $11 \%$ and $19 \%$ increase in dry matter and a 5.7-fold increase in ascorbate in fruit (Table 4) [102]. In addition to the results obtained from growth in high $\mathrm{CO}_{2}$, this supports the idea that enhancing $\mathrm{CO}_{2}$ uptake can positively influence the Vitamin $\mathrm{C}$ content of foods.

\subsection{Tocopherols (Vitamin E)}

Vitamin $\mathrm{E}$ is a fat soluble group of compounds including four tocopherols and four tocotrienols, the most active of which is $\alpha$-tocopherol (Figure 5). It functions to protect cell membranes from reactive oxygen species, the result of which can be nerve damage. Furthermore, vitamin E deficiency is responsible for a number of conditions including impairment of immune responses, myopathies, retinopathy, peripheral neuropathy and ataxia (progressive neurodegenerative disorder). However, Vitamin E deficiency is humans is rare and is usually the consequence of a metabolic disorder rather than a lack of Vitamin E in the diet. To enhance Vitamin E content in Corn, Cahoon et al. [152,223] over-expressed cDNAs encoding homogentisic acid geranylgeranyl transferase (HGGT), resulting in a 10- to 15-fold increase in total vitamin E antioxidants (tocotrienols plus tocopherols). This was further demonstrated in Sorghum by Che et al. [136] who over-expressed HGGT in combination with the over-expression of cDNA encoding carotenoid biosynthetic enzymes (Table 2). These authors demonstrated that with this combination of genes, transgenic sorghum could accumulate all-trans $\beta$-carotene ( 19-fold increase see Section 3.1) and a 1.8-fold and 1.7-fold increase in $\alpha$-tocopherol and $\gamma$-tocopherol, respectively, and a 27-fold increase in $\alpha$-tocotrienol [136].

\subsection{A Multi-Targeted Approach to Multi-Vitamin Crops}

Previous studies have used multigene targeted approaches to increase the nutritional content of various crops; however, Naqvi et al. [149] used a multigene, multivitamin approach to boost three vitamins from three distinct metabolic pathways, namely Vitamin C, folate and provitamin A in South African Corn. Naqvi et al. over-expressed the Pantoea ananatis carotene desaturase (CRTI) and Maize psy (Figure 3A) to increase $\beta$-carotene (provitamin A) from $0.35 \mu \mathrm{g} / \mathrm{g}$ DW to $15-59 \mu \mathrm{g} / \mathrm{g}$ DW in the best lines and up to a 100-fold increase in total carotenoids including increases in $\alpha$-carotene and $\beta$-cryptoxanthin, which also serve as substrate for vitamin A (Table 2; see Section 3.1). In the same plants, these authors expressed the Esherichia. coli folE, encoding GTP cyclohydrolase I (GCHI: Figure $4 \mathrm{~B}$ ) and the rice dehydroascorbate reductase (DHAR: Enzyme 13: Figure 6) to increase folate 
and vitamin C content by $\sim 2$-fold (Table 3; see Section 3.2) and up to 7.5-fold, respectively (Table 4; See Section 3.4).

\section{Future Prospects and Conclusions}

With increasing requirements for food and fuel, the need to develop varieties of important crops with greater yields is at the forefront of agriculture. In recent years, using genetic manipulation to increase the rate of photosynthesis as a means of increasing yields has also gained traction. Evidence supporting this has come from both modelling approaches and from initial work looking at the over-expression of single genes in a variety of transgenic plants. Later, a multi-targeted approach to genetic manipulation further supported the idea that manipulating multiple targets in $C B C$, photorespiration and electron transport could have a synergistic effect resulting in greater increases in yield. Furthermore, growing carrots, strawberry, tomato, celery and citrus in elevated $\left[\mathrm{CO}_{2}\right]$ resulted in an increase in vitamin $\mathrm{C}$ content, demonstrating that increasing $\mathrm{CO}_{2}$ assimilation has the potential to increase nutritional content. These data also suggest that manipulating photosynthesis to improve $\mathrm{CO}_{2}$ assimilation without increasing atmospheric $\left[\mathrm{CO}_{2}\right]$ could potentially also result in increases in plant vitamin content. However, this situation may be more complex and species specific. Cober et al. [224] reported that growing soybean in elevated $\left[\mathrm{CO}_{2}\right]$ resulted in an increase in seed yield but seed oil concentrations and seed protein levels were reduced. Furthermore, a meta-analysis carried out by Myers et al. [225] reported that $C_{3}$ plants and legumes grown under elevated $\left[\mathrm{CO}_{2}\right.$ ] had lower concentrations of zinc and iron; and in non-legume $\mathrm{C}_{3}$ plants a reduction of protein content. Zhu et al. [226] confirmed these results and also demonstrated declines in vitamins B1, B2, B5, and B9 in Rice grown under high $\left[\mathrm{CO}_{2}\right]$. Interestingly, these authors also observed an increase in vitamin $\mathrm{E}$ (see Section 3.5) in these same plants. With global increases in atmospheric $\left[\mathrm{CO}_{2}\right]$, temperature and rainfall, these results demonstrate that climate change could significantly impact the nutritional quality of our crops.

Biotechnology programs are at the forefront of agricultural research and adopting techniques such as genetic engineering and genome editing for endogenous genes manipulation [227-229] is key to tackle these issues. To generate plants with sustainable increases in yields and nutritional quality, and with the ability to adapt successfully to changing environmental conditions, will require a multi-targeted approach touching upon multiple aspects of carbon assimilation, light adaptation and nutrient biosynthesis and will require new tools including vectors for multiple gene insertion [230-234] and tissue-specific promoters [235-240]. If the promise of these biotechnology programs is to be realized, public perception of genetic modification and genome editing technologies will need to be addressed. 'Golden Rice', for example, biofortified with pro-vitamin A, was engineered by a team of European scientists with the hope of combatting premature blindness and early death caused by vitamin A deficiencies in human populations that subsist on nutrient poor white rice. However, 20 year later, Golden rice has failed to reach these populations and it has been reported that tens of millions of people in countries including China, Bangladesh, and South and Southeast Asia have died or gone blind [241]. Golden rice has been described by critics as a 'hoax', as 'fool's gold' and as propaganda for GM technologies and supporters have described the 20 years delay in its introduction as a crime against humanity [241]. Finally, all countries have in place, regulatory mechanisms for the approval of GM crops; however, these differ significantly and are often complicated by non-science based systems [242-244]. A more streamlined long-term approach may be needed for international adoption of these technologies.

Previous work has shown that manipulating the expression levels of genes for provitamin A, Folate and vitamin $C$ metabolism can result in an increase in these micronutrients and that combining these manipulations results in multivitamin corn. This research opens the avenue of manipulating photosynthesis and vitamin metabolism to create high yielding multivitamin crops for addressing 'hunger' and 'hidden hunger' in at risk populations. 
Funding: This research received no external funding.

Conflicts of Interest: The author declares no conflict of interest.

\section{References}

1. Zhu, X.G.; Long, S.P.; Ort, D.R. Improving photosynthetic efficiency for greater yield. Annu. Rev. Plant Biol. 2010, 61, 235-261. [CrossRef]

2. Lawson, T.; Kramer, D.M.; Raines, C.A. Improving yield by exploiting mechanisms underlying natural variation of photosynthesis. Curr. Opin. Biotechnol. 2012, 23, 215-220. [CrossRef]

3. Driever, S.M.; Lawson, T.; Andralojc, P.J.; Raines, C.A.; Parry, M.A. Natural variation in photosynthetic capacity, growth, and yield in 64 field-grown wheat genotypes. J. Exp. Bot. 2014, 65, 4959-4973. [CrossRef]

4. Food and Agriculture Organization of the United Nations (FAO). State of Food Insecurity in the World 2015; FAO: Rome, Italy, 2015.

5. United Nations Desa Population Division. World Population Prospects 2019: Data Booklet. Available online: https://population.un.org/wpp/Publications/Files/WPP2019_DataBooklet.pdf (accessed on 19 November 2019).

6. Fischer, R.A.T.; Edmeades, G.O. Breeding and cereal yield progress. Crop. Sci. 2010, 50, S85-S98. [CrossRef]

7. Long, S.P.; Marshall-Colon, A.; Zhu, X.G. Meeting the global food demand of the future by engineering crop photosynthesis and yield potential. Cell 2015, 161, 56-66. [CrossRef]

8. Ort, D.R.; Merchant, S.S.; Alric, J.; Barkan, A.; Blankenship, R.E.; Bock, R.; Croce, R.; Hanson, M.R.; Hibberd, J.M.; Long, S.P.; et al. Redesigning photosynthesis to sustainably meet global food and bioenergy demand. Proc. Natl. Acad. Sci. USA 2015, 112, 8529-9536. [CrossRef]

9. Ray, D.K.; Mueller, N.D.; West, P.C.; Foley, J.A. Yield trends are insufficient to double global crop production by 2050. PLoS ONE 2013, 8, e66428. [CrossRef]

10. RSOL. Royal Society of London, Reaping the Benefits: Science and the Sustainable Intensification of Global Agriculture; Royal Society: London, UK, 2009.

11. Tilman, D.; Balzer, C.; Hill, J.; Befort, B.L. Global food demand and the sustainable intensification of agriculture. Proc. Natl. Acad. Sci. USA 2011, 108, 20260-20264. [CrossRef]

12. World Bank. World Development Report 2008: Agriculture for Development; World Bank: Washington, DC, USA, 2008.

13. Dirzo, R.; Raven, P.H. Global state of biodiversity and loss. Annu. Rev. Environ. Resour. 2003, 28, $137-167$. [CrossRef]

14. Godfray, H.C.J.; Beddington, J.R.; Crute, I.R.; Haddad, L.; Lawrence, D.; Muir, J.F.; Pretty, J.; Robinson, S.; Thomas, S.M.; Toulmin, C. Food security: The challenge of feeding 9 billion people. Science 2010, 327, 812-818. [CrossRef]

15. Godfray, H.C.J. The challenge of feeding 9-10 billion people equitably and sustainably. J. Agric. Sci. 2014, 152, S2-S8. [CrossRef]

16. GOFS. The Government Office for Science Foresight. The Future of Food and Farming. Final Project Report; The Government Office for Science: London, UK, 2011.

17. Vitousek, P.M.; Aber, J.D.; Howarth, R.W.; Likens, G.E.; Matson, P.A.; Schindler, D.W.; Schlesinger, W.H.; Tilman, D. Human alteration of the global nitrogen cycle: Sources and consequences. Ecol. Appl. 1997, 7, 737-750. [CrossRef]

18. Burney, J.A.; Davis, S.J.; Lobell, D.B. Greenhouse gas mitigation by agricultural intensification. Proc. Natl. Acad. Sci. USA 2010, 107, 12052-12057. [CrossRef]

19. Bouis, H.E.; Eozenou, P.; Rahman, A. Food prices, household income, and resource allocation: Socioeconomic perspectives on their effects on dietary quality and nutritional status. Food Nutr. Bull. 2011, 32, S14-S23. [CrossRef]

20. Johnson, M.P. Photosynthesis. Essays Biochem. 2016, 60, 255-273. [CrossRef]

21. Parry, M.A.J.; Andralojc, P.J.; Scales, J.C.; Salvucci, M.E.; Carmo-Silva, A.E.; Alonso, H.; Whitney, S.M. Rubisco activity and regulation as targets for crop improvement. J. Exp. Bot. 2013, 64, 717-730. [CrossRef]

22. Wu, A.; Hammer, G.L.; Doherty, A.; von Caemmerer, S.; Farquhar, G.D. Quantifying impacts of enhancing photosynthesis on crop yield. Nat. Plants 2019, 5, 380-388. [CrossRef]

23. Simkin, A.J.; Lopez-Calcagno, P.E.; Raines, C.A. Feeding the world: Improving photosynthetic efficiency for sustainable crop production. J. Exp. Bot. 2019, 70, 1119-1140. [CrossRef] 
24. Orr, D.J.; Pereira, A.M.; da Fonseca Pereira, P.; Pereira-Lima, I.A.; Zsogon, A.; Araujo, W.L. Engineering photosynthesis: Progress and perspectives. F1000 Res. 2017, 6, 1891. [CrossRef]

25. Bassham, J.A.; Calvin, M. The path of carbon in photosynthesis. In Die $\mathrm{CO}_{2}$-Assimilation / the Assimilation of Carbon Dioxide: In 2 Teilen / 2 Parts; Pirson, A., Ed.; Springer: Berlin/Heidelberg, Germany, 1960; pp. 884-922.

26. Calvin, M.; Benson, A.A. The path of carbon in photosynthesis. Science 1948, 107, 476-480. [CrossRef]

27. Lawson, T.; Bryant, B.; Lefebvre, S.; Lloyd, J.C.; Raines, C.A. Decreased sbpase activity alters growth and development in transgenic tobacco plants. Plant Cell Environ. 2006, 29, 48-58. [CrossRef]

28. Harrison, E.P.; Olcer, H.; Lloyd, J.C.; Long, S.P.; Raines, C.A. Small decreases in sbpase cause a linear decline in the apparent rubp regeneration rate, but do not affect rubisco carboxylation capacity. J. Exp. Bot. 2001, 52, 1779-1784. [CrossRef]

29. Harrison, E.P.; Willingham, N.M.; Lloyd, J.C.; Raines, C.A. Reduced sedoheptulose-1,7-bisphosphatase levels in transgenic tobacco lead to decreased photosynthetic capacity and altered carbohydrate accumulation. Planta 1998, 204, 27-36. [CrossRef]

30. Haake, V.; Geiger, M.; Walch-Liu, P.; Engels, C.; Zrenner, R.; Stitt, M. Changes in aldolase activity in wild-type potato plants are important for acclimation to growth irradiance and carbon dioxide concentration, because plastid aldolase exerts control over the ambient rate of photosynthesis across a range of growth conditions. Plant J. 1999, 17, 479-489. [CrossRef]

31. Haake, V.; Zrenner, R.; Sonnewald, U.; Stitt, M. A moderate decrease of plastid aldolase activity inhibits photosynthesis, alters the levels of sugars and starch, and inhibits growth of potato plants. Plant J. 1998, 14, 147-157. [CrossRef]

32. Kossmann, J.; Muller-Rober, B.; Dyer, T.A.; Raines, C.A.; Sonnewald, U.; Willmitzer, L. Cloning and expression analysis of the plastidic fructose-1,6-bisphosphatase coding sequence from potato: Circumstantial evidence for the import of hexoses into chloroplasts. Planta 1992, 188, 7-12. [CrossRef]

33. Rojas-Gonzalez, J.A.; Soto-Suarez, M.; Garcia-Diaz, A.; Romero-Puertas, M.C.; Sandalio, L.M.; Merida, A.; Thormahlen, I.; Geigenberger, P.; Serrato, A.J.; Sahrawy, M. Disruption of both chloroplastic and cytosolic fbpase genes results in a dwarf phenotype and important starch and metabolite changes in arabidopsis thaliana. J. Exp. Bot. 2015, 66, 2673-2689. [CrossRef]

34. Sahrawy, M.; Avila, C.; Chueca, A.; Canovas, F.M.; Lopez-Gorge, J. Increased sucrose level and altered nitrogen metabolism in arabidopsis thaliana transgenic plants expressing antisense chloroplastic fructose-1,6-bisphosphatase. J. Exp. Bot. 2004, 55, 2495-2503. [CrossRef]

35. Paul, M.J.; Driscoll, S.P.; Andralojc, P.J.; Knight, J.S.; Gray, J.C.; Lawlor, D.W. Decrease of phosphoribulokinase activity by antisense rna in transgenic tobacco: Definition of the light environment under which phosphoribulokinase is not in large excess. Planta 2000, 211, 112-119. [CrossRef]

36. Raines, C.A. The calvin cycle revisited. Photosynth. Res. 2003, 75, 1-10. [CrossRef]

37. Stitt, M.; Schulze, D. Does rubisco control the rate of photosynthesis and plant-growth - an exercise in molecular ecophysiology. Plant Cell Environ. 1994, 17, 465-487. [CrossRef]

38. Ainsworth, E.A.; Long, S.P. What have we learned from 15 years of free-air $\mathrm{CO}_{2}$ enrichment (face)? A meta-analytic review of the responses of photosynthesis, canopy. N. Phytol. 2005, 165, 351-371. [CrossRef]

39. Raines, C.A. Transgenic approaches to manipulate the environmental responses of the $c 3$ carbon fixation cycle. Plant Cell Environ. 2006, 29, 331-339. [CrossRef]

40. Lefebvre, S.; Lawson, T.; Fryer, M.; Zakhleniuk, O.V.; Lloyd, J.C.; Raines, C.A. Increased sedoheptulose-1,7-bisphosphatase activity in transgenic tobacco plants stimulates photosynthesis and growth from an early stage in development. Plant Physiol. 2005, 138, 451-460. [CrossRef]

41. Simkin, A.J.; McAusland, L.; Headland, L.R.; Lawson, T.; Raines, C.A. Multigene manipulation of photosynthetic carbon assimilation increases $\mathrm{CO}_{2}$ fixation and biomass yield in tobacco. J. Exp. Bot. 2015, 66, 4075-4090. [CrossRef]

42. Simkin, A.J.; Lopez-Calcagno, P.E.; Davey, P.A.; Headland, L.R.; Lawson, T.; Timm, S.; Bauwe, H.; Raines, C.A. Simultaneous stimulation of sedoheptulose 1,7-bisphosphatase, fructose 1,6-bisphophate aldolase and the photorespiratory glycine decarboxylase h-protein increases $\mathrm{CO}_{2}$ assimilation, vegetative biomass and seed yield in arabidopsis. Plant Biotechnol. J. 2017, 15, 805-816. [CrossRef]

43. Ding, F.; Wang, M.; Zhang, S.; Ai, X. Changes in sbpase activity influence photosynthetic capacity, growth, and tolerance to chilling stress in transgenic tomato plants. Sci. Rep. 2016, 6, 32741. [CrossRef] 
44. Rosenthal, D.M.; Locke, A.M.; Khozaei, M.; Raines, C.A.; Long, S.P.; Ort, D.R. Over-expressing the c3 photosynthesis cycle enzyme sedoheptulose-1-7 bisphosphatase improves photosynthetic carbon gain and yield under fully open air $\mathrm{CO}_{2}$ fumigation (face). BMC Plant Biol. 2011, 11, 123. [CrossRef]

45. Driever, S.M.; Simkin, A.J.; Alotaibi, S.; Fisk, S.J.; Madgwick, P.J.; Sparks, C.A.; Jones, H.D.; Lawson, T.; Parry, M.A.J.; Raines, C.A. Increased sbpase activity improves photosynthesis and grain yield in wheat grown in greenhouse conditions. Philos. Trans. R. Soc. B 2017, 372, 1730. [CrossRef]

46. Uematsu, K.; Suzuki, N.; Iwamae, T.; Inui, M.; Yukawa, H. Increased fructose 1,6-bisphosphate aldolase in plastids enhances growth and photosynthesis of tobacco plants. J. Exp. Bot. 2012, 63, 3001-3009. [CrossRef]

47. Khozaei, M.; Fisk, S.; Lawson, T.; Gibon, Y.; Sulpice, R.; Stitt, M.; Lefebvre, S.C.; Raines, C.A. Overexpression of plastid transketolase in tobacco results in a thiamine auxotrophic phenotype. Plant Cell 2015, 27, 432-447. [CrossRef]

48. Ludwig, L.J.; Canvin, D.T. The rate of photorespiration during photosynthesis and the relationship of the substrate of light respiration to the products of photosynthesis in sunflower leaves. Plant Physiol. 1971, 48, 712-719. [CrossRef]

49. Walker, B.J.; VanLoocke, A.; Bernacchi, C.J.; Ort, D.R. The costs of photorespiration to food production now and in the future. Annu. Rev. Plant Biol. 2016, 67, 107. [CrossRef]

50. Walker, B.J.; South, P.F.; Ort, D.R. Physiological evidence for plasticity in glycolate/glycerate transport during photorespiration. Photosynth. Res. 2016, 129, 93-103. [CrossRef]

51. Tolbert, N.E. The c2 oxidative photosynthetic carbon cycle. Annu. Rev. Plant Physiol. Plant Mol. Biol. 1997, 48, 1-25. [CrossRef]

52. Bowes, G.; Ogren, W.L.; Hageman, R.H. Phosphoglycolate production catalyzed by ribulose diphosphate carboxylase. Biochem. Biophys. Res. Commun. 1971, 45, 716. [CrossRef]

53. Anderson, L.E. Chloroplast and cytoplasmic enzymes. 2. Pea leaf triose phosphate isomerases. Biochim. Biophys. Acta 1971, 235, 237. [CrossRef]

54. Sharkey, T.D. Estimating the rate of photorespiration in leaves. Physiol. Plant. 1988, 73, 147-152. [CrossRef]

55. Busch, F.A. Current methods for estimating the rate of photorespiration in leaves. Plant Biol. 2013, 15, 648-655. [CrossRef]

56. Heineke, D.; Bykova, N.; Gardestrom, P.; Bauwe, H. Metabolic response of potato plants to an antisense reduction of the p-protein of glycine decarboxylase. Planta 2001, 212, 880-887. [CrossRef]

57. Lin, H.C.; Karki, S.; Coe, R.A.; Bagha, S.; Khoshravesh, R.; Balahadia, C.P.; Sagun, J.V.; Tapia, R.; Israel, W.K.; Montecillo, F.; et al. Targeted knockdown of gdch in rice leads to a photorespiratory-deficient phenotype useful as a building block for c4 rice. Plant Cell Physiol. 2016, 57, 919-932. [CrossRef]

58. Zhou, Q.Y.; Yu, Q.; Wang, Z.Q.; Pan, Y.F.; Lv, W.T.; Zhu, L.L.; Chen, R.Z.; He, G.C. Knockdown of gdch gene reveals reactive oxygen species-induced leaf senescence in rice. Plant Cell Environ. 2013, 36, 1476-1489. [CrossRef]

59. Bykova, N.V.; Keerberg, O.; Parnik, T.; Bauwe, H.; Gardestrom, P. Interaction between photorespiration and respiration in transgenic potato plants with antisense reduction in glycine decarboxylase. Planta 2005, 222, 130-140. [CrossRef]

60. Timm, S.; Florian, A.; Arrivault, S.; Stitt, M.; Fernie, A.R.; Bauwe, H. Glycine decarboxylase controls photosynthesis and plant growth. FEBS Lett. 2012, 586, 3692-3697. [CrossRef]

61. Timm, S.; Florian, A.; Fernie, A.R.; Bauwe, H. The regulatory interplay between photorespiration and photosynthesis. J. Exp. Bot. 2016, 67, 2923-2929. [CrossRef]

62. Timm, S.; Wittmiss, M.; Gamlien, S.; Ewald, R.; Florian, A.; Frank, M.; Wirtz, M.; Hell, R.; Fernie, A.R.; Bauwea, $\mathrm{H}$. Mitochondrial dihydrolipoyl dehydrogenase activity shapes photosynthesis and photorespiration of arabidopsis thaliana. Plant Cell 2015, 27, 1968-1984. [CrossRef]

63. López-Calcagno, P.E.; Fisk, S.J.; Brown, K.; Bull, S.E.; South, P.F.; Raines, C.A. Overexpressing the h-protein of the glycine cleavage system increases biomass yield in glasshouse and field-grown transgenic tobacco plants. Plant Biotechnol. J. 2018, 17, 141-151. [CrossRef]

64. Kelly, G.J.; Latzko, E. Inhibition of spinach leaf phosphofructokinase by 2-phosphoglycollate. FEBS Lett. 1976, 68, 55-58. [CrossRef]

65. Eisenhut, M.; Bauwe, H.; Hagemann, M. Glycine accumulation is toxic for the cyanobacterium synechocystis sp strain pcc 6803 , but can be compensated by supplementation with magnesium ions. Fems. Microbiol. Lett. 2007, 277, 232-237. [CrossRef] 
66. Lu, Y.S.; Li, Y.; Yang, Q.S.; Zhang, Z.S.; Chen, Y.; Zhang, S.; Peng, X.X. Suppression of glycolate oxidase causes glyoxylate accumulation that inhibits photosynthesis through deactivating rubisco in rice. Physiol. Plant. 2014, 150, 463-476. [CrossRef]

67. Cook, C.M.; Mulligan, R.M.; Tolbert, N.E. Inhibition and stimulation of ribulose-1,5-bisphosphate carboxylase-oxygenase by glyoxylate. Arch. Biochem. Biophys. 1985, 240, 392-401. [CrossRef]

68. Campbell, W.J.; Ogren, W.L. Glyoxylate inhibition of ribulosebisphosphate carboxylase/oxygenase activation in intact, lysed, and reconstituted chloroplasts. Photosynth. Res. 1990, 23, 257-268. [CrossRef]

69. Chastain, C.J.; Ogren, W.L. Glyoxylate inhibition of ribulosebisphosphate carboxylase/oxygenase activation state In Vivo. Plant Cell Physiol. 1989, 30, 937-944.

70. Flugel, F.; Timm, S.; Arrivault, S.; Florian, A.; Stitt, M.; Fernie, A.R.; Bauwe, H. The photorespiratory metabolite 2-phosphoglycolate regulates photosynthesis and starch accumulation in arabidopsis. Plant Cell 2017, 29, 2537-2551. [CrossRef]

71. Hausler, R.E.; Bailey, K.J.; Lea, P.J.; Leegood, R.C. Control of photosynthesis in barley mutants with reduced activities of glutamine synthetase and glutamate synthase.3. Aspects of glyoxylate metabolism and effects of glyoxylate on the activation state of ribulose-1, 5-bisphosphate carboxylase-oxygenase. Planta 1996, 200, 388-396. [CrossRef]

72. Roach, T.; Krieger-Liszkay, A. Regulation of photosynthetic electron transport and photoinhibition. Curr. Protein Pept. Sci. 2014, 15, 351-362. [CrossRef]

73. Chida, H.; Nakazawa, A.; Akazaki, H.; Hirano, T.; Suruga, K.; Ogawa, M.; Satoh, T.; Kadokura, K.; Yamada, S.; Hakamata, W.; et al. Expression of the algal cytochrome $c_{6}$ gene in arabidopsis enhances photosynthesis and growth. Plant Cell Physiol. 2007, 48, 948-957. [CrossRef]

74. Yadav, S.K.; Khatri, K.; Rathore, M.S.; Jha, B. Introgression of ufcyt $\mathrm{c}_{6}$, a thylakoid lumen protein from a green seaweed ulva fasciata delile enhanced photosynthesis and growth in tobacco. Mol. Biol. Rep. 2018, 45, 1745-1758. [CrossRef]

75. Merchant, S.; Bogorad, L. The cu(ii)-repressible plastidic cytochrome $c$. Cloning and sequence of a complementary DNA for the pre-apoprotein. J. Biol. Chem. 1987, 262, 9062-9067.

76. Simkin, A.J.; McAusland, L.; Lawson, T.; Raines, C.A. Over-expression of the rieskefes protein increases electron transport rates and biomass yield. Plant Physiol. 2017, 175, 134-145. [CrossRef]

77. Ermakova, M.; Lopez-Calcagno, P.E.; Raines, C.A.; Furbank, R.T.; von Caemmerer, S. Overexpression of the rieske fes protein of the cytochrome $b_{6} f$ complex increases 44 photosynthesis in setaria viridis. Commun. Biol. 2019, 2, 314. [CrossRef]

78. Price, G.D.; Yu, J.W.; Voncaemmerer, S.; Evans, J.R.; Chow, W.S.; Anderson, J.M.; Hurry, V.; Badger, M.R. Chloroplast cytochrome $b_{6} f$ and atp synthase complexes in tobacco-transformation with antisense RNA against nuclear-encoded transcripts for the rieske fes and atp-delta polypeptides. Aust. J. Plant Physiol. 1995, 22, 285-297.

79. Price, G.D.; von Caemmerer, S.; Evans, J.R.; Siebke, K.; Anderson, J.M.; Badger, M.R. Photosynthesis is strongly reduced by antisense suppression of chloroplastic cytochrome $b_{6} f$ complex in transgenic tobacco. Aust. J. Plant Physiol. 1998, 25, 445-452.

80. Anderson, J.M.; Price, G.D.; Chow, W.S.; Hope, A.B.; Badger, M.R. Reduced levels of cytochrome $b f$ complex in transgenic tobacco leads to marked photochemical reduction of the plastoquinone pool, without significant change in acclimation to irradiance. Photosynth. Res. 1997, 53, 215-227. [CrossRef]

81. Ruuska, S.A.; Andrews, T.J.; Badger, M.R.; Price, G.D.; von Caemmerer, S. The role of chloroplast electron transport and metabolites in modulating rubisco activity in tobacco. Insights from transgenic plants with reduced amounts of cytochrome b/f complex or glyceraldehyde 3-phosphate dehydrogenase. Plant Physiol. 2000, 122, 491-504. [CrossRef]

82. Yamori, W.; Takahashi, S.; Makino, A.; Price, G.D.; Badger, M.R.; von Caemmerer, S. The roles of atp synthase and the cytochrome $b_{6} / f$ complexes in limiting chloroplast electron transport and determining photosynthetic capacity. Plant Physiol. 2011, 155, 956-962. [CrossRef]

83. Yamori, W.; Sakata, N.; Suzuki, Y.; Shikanai, T.; Makino, A. Cyclic electron flow around photosystem i via chloroplast nad(p)h dehydrogenase (ndh) complex performs a significant physiological role during photosynthesis and plant growth at low temperature in rice. Plant J. 2011, 68, 966-976. [CrossRef] 
84. Hurry, V.; Anderson, J.M.; Badger, M.R.; Price, G.D. Reduced levels of cytochrome b(6)lf in transgenic tobacco increases the excitation pressure on photosystem ii without increasing sensitivity to photoinhibition in vivo. Photosynth. Res. 1996, 50, 159-169. [CrossRef]

85. Yamamoto, H.; Kato, H.; Shinzaki, Y.; Horiguchi, S.; Shikanai, T.; Hase, T.; Endo, T.; Nishioka, M.; Makino, A.; Tomizawa, K.-i.; et al. Ferredoxin limits cyclic electron flow around psi (cef-psi) in higher plants—stimulation of cef-psi enhances non-photochemical quenching of chl fluorescence in transplastomic tobacco. Plant Cell Physiol. 2006, 47, 1355-1371. [CrossRef]

86. Rodriguez, R.E.; Lodeyro, A.; Poli, H.O.; Zurbriggen, M.; Peisker, M.; Palatnik, J.F.; Tognetti, V.B.; Tschiersch, H.; Hajirezaei, M.-R.; Valle, E.M.; et al. Transgenic tobacco plants overexpressing chloroplastic ferredoxin-nadp $(\mathrm{h})$ reductase display normal rates of photosynthesis and increased tolerance to oxidative stress. Plant Physiol. 2007, 143, 639-649. [CrossRef]

87. Chang, H.; Huang, H.-E.; Cheng, C.-F.; Ho, M.-H.; Ger, M.-J. Constitutive expression of a plant ferredoxin-like protein (pflp) enhances capacity of photosynthetic carbon assimilation in rice (oryza sativa). Transgenic Res. 2017, 26, 279-289. [CrossRef]

88. Gong, H.Y.; Li, Y.; Fang, G.; Hu, D.H.; Jin, W.B.; Wang, Z.H.; Li, Y.S. Transgenic rice expressing ictb and $\mathrm{fbp} / \mathrm{sbpase}$ derived from cyanobacteria exhibits enhanced photosynthesis and mesophyll conductance to $\mathrm{CO}_{2}$. PLoS ONE 2015, 10, e0140928. [CrossRef]

89. Simkin, A.J.; Faralli, M.; Ramamoorthy, S.; Lawson, T. Photosynthesis in non-foliar tissues: Implications for yield. Plant J. 2019. [CrossRef]

90. Hibberd, J.M.; Quick, W.P. Characteristics of c4 photosynthesis in stems and petioles of c3 flowering plants. Nature 2002, 415, 451-454. [CrossRef]

91. Schwender, J.; Goffman, F.; Ohlrogge, J.B.; Shachar-Hill, Y. Rubisco without the calvin cycle improves the carbon efficiency of developing green seeds. Nature 2004, 432, 779-782. [CrossRef]

92. Hiratsuka, S.; Suzuki, M.; Nishimura, H.; Nada, K. Fruit photosynthesis in satsuma mandarin. Plant Sci. 2015, 241, 65-69. [CrossRef]

93. Sui, X.; Shan, N.; Hu, L.; Zhang, C.; Yu, C.; Ren, H.; Turgeon, R.; Zhang, Z. The complex character of photosynthesis in cucumber fruit. J. Exp. Bot. 2017, 68, 1625-1637. [CrossRef]

94. Hetherington, S.E.; Smillie, R.M.; Davies, W.J. Photosynthetic activities of vegetative and fruiting tissues of tomato. J. Exp. Bot. 1998, 49, 1173-1181. [CrossRef]

95. Carrara, S.; Pardossi, A.; Soldatini, G.F.; Tognoni, F.; Guidi, L. Photosynthetic activity of ripening tomato fruit. Photosynthetica 2001, 39, 75-78. [CrossRef]

96. Maydup, M.L.; Antonietta, M.; Guiamet, J.J.; Graciano, C.; Lopez, J.R.; Tambussi, E.A. The contribution of ear photosynthesis to grain filling in bread wheat. Field Crop. Res. 2010, 119, 48-58. [CrossRef]

97. Pengelly, J.J.L.; Kwasny, S.; Bala, S.; Evans, J.R.; Voznesenskaya, E.V.; Koteyeva, N.K.; Edwards, G.E.; Furbank, R.T.; von Caemmerer, S. Functional analysis of corn husk photosynthesis. Plant Physiol. 2011, 156, 503-513. [CrossRef]

98. Idso, S.B.; Kimball, B.A.; Shaw, P.E.; Widmer, W.; Vanderslice, J.T.; Higgs, D.J.; Montanari, A.; Clark, W.D. The effect of elevated atmospheric $\mathrm{CO}_{2}$ on the vitamin c concentration of (sour) orange juice. Agric. Ecosyst. Environ. 2002, 90,1-7. [CrossRef]

99. Wang, S.Y.; Bunce, J.A.; Maas, J.L. Elevated carbon dioxide increases contents of antioxidant compounds in field-grown strawberries. J. Agric. Food Chem. 2003, 51, 4315-4320. [CrossRef]

100. Mamatha, H.; Srinivasa Rao, N.K.; Laxman, R.H.; Shivashankara, K.S.; Bhatt, R.M.; Pavithra, K.C. Impact of elevated $\mathrm{CO}_{2}$ on growth, physiology, yield, and quality of tomato (lycopersicon esculentum mill) cv. Arka ashish. Photosynthetica 2014, 52, 519-528. [CrossRef]

101. Wu, X.-J.; Sun, S.; Xing, G.-M.; Wang, G.-L.; Wang, F.; Xu, Z.-S.; Tian, Y.-S.; Hou, X.-L.; Xiong, A.-S. Elevated carbon dioxide altered morphological and anatomical characteristics, ascorbic acid accumulation, and related gene expression during taproot development in carrots. Front. Plant Sci. 2017, 7, 2026. [CrossRef] [PubMed]

102. Nunes-Nesi, A.; Carrari, F.; Lytovchenko, A.; Smith, A.M.O.; Ehlers Loureiro, M.; Ratcliffe, R.G.; Sweetlove, L.J.; Fernie, A.R. Enhanced photosynthetic performance and growth as a consequence of decreasing mitochondrial malate dehydrogenase activity in transgenic tomato plants. Plant Physiol. 2005, 137, 611-622. [CrossRef] [PubMed]

103. Bouis, H.E.; Saltzman, A. Improving nutrition through biofortification: A review of evidence from harvestplus, 2003 through 2016. Glob. Food Secur. 2017, 12, 49-58. [CrossRef] 
104. Nisar, N.; Li, L.; Lu, S.; Khin, N.C.; Pogson, B.J. Carotenoid metabolism in plants. Mol. Plant 2015, 8, 68-82. [CrossRef] [PubMed]

105. Josse, E.M.; Simkin, A.J.; Gaffe, J.; Laboure, A.M.; Kuntz, M.; Carol, P. A plastid terminal oxidase associated with carotenoid desaturation during chromoplast differentiation. Plant Physiol. 2000, 123, 1427-1436. [CrossRef]

106. De Moura, F.F.; Miloff, A.; Boy, E. Retention of provitamin a carotenoids in staple crops targeted for biofortification in africa: Cassava, maize and sweet potato. Crit. Rev. Food Sci. Nutr. 2015, 55, 1246-1269. [CrossRef]

107. Telfer, A. What is beta-carotene doing in the photosystem ii reaction centre? Philos. Trans. R. Soc. Lond. Ser. B Biol. Sci. 2002, 357, 1431-1439. [CrossRef]

108. Von Lintig, J.; Dreher, A.; Kiefer, C.; Wernet, M.F.; Vogt, K. Analysis of the blind drosophila mutant ninab identifies the gene encoding the key enzyme for vitamin a formation invivo. Proc. Natl. Acad. Sci. USA 2001, 98, 1130-1135. [CrossRef]

109. Wyss, A.; Wirtz, G.; Woggon, W.; Brugger, R.; Wyss, M.; Friedlein, A.; Bachmann, H.; Hunziker, W. Cloning and expression of beta,beta-carotene 15,15'-dioxygenase. Biochem. Biophys. Res. Commun. 2000, 271, 334-336. [CrossRef]

110. Lindqvist, A.; Andersson, S. Biochemical properties of purified recombinant human beta-carotene 15, 15'-monooxygenase. J. Biol. Chem. 2002, 277, 23942-23948. [CrossRef] [PubMed]

111. Saini, R.K.; Shang, X.M.; Ko, E.Y.; Choi, J.H.; Keum, Y.-S. Stability of carotenoids and tocopherols in ready-to-eat baby-leaf lettuce and salad rocket during low-temperature storage. Int. J. Food Sci. Nutr. 2016, 67, 489-495. [CrossRef]

112. Ruiz, D.; Egea, J.; Tomas-Barberan, F.A.; Gil, M.I. Carotenoids from new apricot (prunus armeniaca 1.) varieties and their relationship with flesh and skin color. J. Agric. Food Chem. 2005, 53, 6368-6374. [CrossRef] [PubMed]

113. Brown, A.F.; Yousef, G.G.; Guzman, I.; Chebrolu, K.K.; Werner, D.J.; Parker, M.; Gasic, K.; Perkins-Veazie, P. Variation of carotenoids and polyphenolics in peach and implications on breeding for modified phytochemical profiles. J. Am. Soc. Hortic. Sci. 2014, 139, 676-686. [CrossRef]

114. Baranska, M.; Baranski, R.; Schulz, H.; Nothnagel, T. Tissue-specific accumulation of carotenoids in carrot roots. Planta 2006, 224, 1028-1037. [CrossRef]

115. Perrin, F.; Hartmann, L.; Dubois-Laurent, C.; Welsch, R.; Huet, S.; Hamama, L.; Briard, M.; Peltier, D.; Gagne, S.; Geoffriau, E. Carotenoid gene expression explains the difference of carotenoid accumulation in carrot root tissues. Planta 2017, 245, 737-747. [CrossRef]

116. Rando, R.R. The chemistry of vitamin a and vision. Angew. Chem. Int. 1990, 29, 461-480. [CrossRef]

117. West, C.E.; Rombout, J.H.; van der Zijpp, A.J.; Sijtsma, S.R. Vitamin a and immune function. Proc. Nutr. Soc. 1991, 50, 251-262. [CrossRef]

118. Tanumihardjo, S.A. Vitamin a: Biomarkers of nutrition for development. Am. J. Clin. Nutr. 2011, 94, 658S-665S. [CrossRef]

119. WHO. World Health Organisation: Micronutrient Deficiencies. Available online: http://www.who.int/ nutrition/topics/vad/en/ (accessed on 19 November 2019).

120. WHO. World Health Organization: Global Prevalence of Vitamin a Deficiency in Populations at Risk 1995-2005. Available online: https://apps.who.int/iris/bitstream/handle/10665/44110/9789241598019_eng.pdf (accessed on 19 November 2019).

121. Hodge, J. Hidden hunger: Approaches to tackling micronutrient deficiencies. In Nourishing Millions: Stories of Change in Nutrition; Gillespie, S., Hodge, J., Yosef, S., Pandya-Lorch, R., Eds.; International Food Policy Research Institute (IFPRI): Washington, DC, USA, 2016; pp. 35-46.

122. Simkin, A.J.; Moreau, H.; Kuntz, M.; Pagny, G.; Lin, C.; Tanksley, S.; McCarthy, J. An investigation of carotenoid biosynthesis in coffea canephora and coffea arabica. J. Plant Physiol. 2008, 165, 1087-1106. [CrossRef]

123. Simkin, A.; McCarthy, J.; Petiard, V.; Lin, C.; Tanksley, S. Polynucleotides Encoding Carotenoid and Apocartenoid Biosynthetic Pathway Enzymes in Coffee. French Patent WO2007028115a2, 8 March 2007.

124. Römer, S.; Fraser, P.D.; Kiano, J.W.; Shipton, C.A.; Misawa, N.; Schuch, W.; Bramley, P.M. Elevation of the provitamin a content of transgenic tomato plants. Nat. Biotechnol. 2000, 18, 666-669. [CrossRef] 
125. Fraser, P.D.; Romer, S.; Shipton, C.A.; Mills, P.B.; Kiano, J.W.; Misawa, N.; Drake, R.G.; Schuch, W.; Bramley, P.M. Evaluation of transgenic tomato plants expressing an additional phytoene synthase in a fruit-specific manner. Proc. Natl. Acad. Sci. USA 2002, 99, 1092-1097. [CrossRef]

126. Simkin, A.J.; Gaffe, J.; Alcaraz, J.P.; Carde, J.P.; Bramley, P.M.; Fraser, P.D.; Kuntz, M. Fibrillin influence on plastid ultrastructure and pigment content in tomato fruit. Phytochemistry 2007, 68, 1545-1556. [CrossRef]

127. Aluru, M.; Xu, Y.; Guo, R.; Wang, Z.; Li, S.; White, W.; Wang, K.; Rodermel, S. Generation of transgenic maize with enhanced provitamin a content. J. Exp. Bot. 2008, 59, 3551-3562. [CrossRef]

128. Strobbe, S.; De Lepeleire, J.; Van Der Straeten, D. From in planta function to vitamin-rich food crops: The ace of biofortification. Frontiers Plant Sci. 2018, 9. [CrossRef]

129. Cong, L.; Wang, C.; Chen, L.; Liu, H.; Yang, G.; He, G. Expression of phytoene synthase1 and carotene desaturase crti genes result in an increase in the total carotenoids content in transgenic elite wheat (triticum aestivum 1.). J. Agric. Food Chem. 2009, 57, 8652-8660. [CrossRef]

130. Shewmaker, C.K.; Sheehy, J.A.; Daley, M.; Colburn, S.; Ke, D.Y. Seed-specific overexpression of phytoene synthase: Increase in carotenoids and other metabolic effects. Plant J. Cell Mol. Biol. 1999, 20, 401-412X. [CrossRef]

131. Diretto, G.; Al-Babili, S.; Tavazza, R.; Papacchioli, V.; Beyer, P.; Giuliano, G. Metabolic engineering of potato carotenoid content through tuber-specific overexpression of a bacterial mini-pathway. PLoS ONE 2007, 2, e350. [CrossRef]

132. Beyene, G.; Solomon, F.R.; Chauhan, R.D.; Gaitan-Solis, E.; Narayanan, N.; Gehan, J.; Siritunga, D.; Stevens, R.L.; Jifon, J.; Van Eck, J.; et al. Provitamin a biofortification of cassava enhances shelf life but reduces dry matter content of storage roots due to altered carbon partitioning into starch. Plant Biotechnol. J. 2018, 16, 1186-1200. [CrossRef]

133. Ducreux, L.J.M.; Morris, W.L.; Hedley, P.E.; Shepherd, T.; Davies, H.V.; Millam, S.; Taylor, M.A. Metabolic engineering of high carotenoid potato tubers containing enhanced levels of $\beta$-carotene and lutein. J. Exp. Bot. 2004, 56, 81-89. [CrossRef]

134. Fujisawa, M.; Misawa, N. Enrichment of carotenoids in flaxseed by introducing a bacterial phytoene synthase gene. Methods Mol. Biol. 2010, 643, 201-211.

135. Fujisawa, M.; Watanabe, M.; Choi, S.K.; Teramoto, M.; Ohyama, K.; Misawa, N. Enrichment of carotenoids in flaxseed (linum usitatissimum) by metabolic engineering with introduction of bacterial phytoene synthase gene crtb. J. Biosci. Bioeng. 2008, 105, 636-641. [CrossRef]

136. Che, P.; Zhao, Z.-Y.; Glassman, K.; Dolde, D.; Hu, T.X.; Jones, T.J.; Gruis, D.F.; Obukosia, S.; Wambugu, F.; Albertsen, M.C. Elevated vitamin e content improves all-trans $\beta$-carotene accumulation and stability in biofortified sorghum. Proc. Natl. Acad. Sci. USA 2016, 113, 11040-11045. [CrossRef]

137. Lipkie, T.E.; De Moura, F.F.; Zhao, Z.-Y.; Albertsen, M.C.; Che, P.; Glassman, K.; Ferruzzi, M.G. Bioaccessibility of carotenoids from transgenic provitamin a biofortified sorghum. J. Agric. Food Chem. 2013, 61, 5764-5771. [CrossRef]

138. Ye, X.; Al-Babili, S.; Kloti, A.; Zhang, J.; Lucca, P.; Beyer, P.; Potrykus, I. Engineering the provitamin a ( $\beta$-carotene) biosynthetic pathway into (carotenoid-free) rice endosperm. Science 2000, 287, 303-305. [CrossRef]

139. Paine, J.A.; Shipton, C.A.; Chaggar, S.; Howells, R.M.; Kennedy, M.J.; Vernon, G.; Wright, S.Y.; Hinchliffe, E.; Adams, J.L.; Silverstone, A.L.; et al. Improving the nutritional value of golden rice through increased pro-vitamin a content. Nat. Biotechnol. 2005, 23, 482-487. [CrossRef]

140. Lu, S.; Van Eck, J.; Zhou, X.; Lopez, A.B.; O’Halloran, D.M.; Cosman, K.M.; Conlin, B.J.; Paolillo, D.J.; Garvin, D.F.; Vrebalov, J.; et al. The cauliflower or gene encodes a DNAj cysteine-rich domain-containing protein that mediates high levels of beta-carotene accumulation. Plant Cell 2006, 18, 3594-3605. [CrossRef]

141. Simkin, A.J.; Laizet, Y.; Kuntz, M. Plastid lipid associated proteins of the fibrillin family: Structure, localisation, functions and gene expression. In Recent Research Developmetns in Biochemistry; Pandalai, S.G., Ed.; Research Signpost: Kerala, India, 2004; Volume 5, pp. 307-316.

142. Yazdani, M.; Sun, Z.; Yuan, H.; Zeng, S.; Thannhauser, T.W.; Vrebalov, J.; Ma, Q.; Xu, Y.; Fei, Z.; Van Eck, J.; et al. Ectopic expression of orange promotes carotenoid accumulation and fruit development in tomato. Plant Biotechnol. J. 2019, 17, 33-49. [CrossRef] 
143. Li, L.; Yang, Y.; Xu, Q.; Owsiany, K.; Welsch, R.; Chitchumroonchokchai, C.; Lu, S.; Van Eck, J.; Deng, X.-X.; Failla, M.; et al. The or gene enhances carotenoid accumulation and stability during post-harvest storage of potato tubers. Mol. Plant 2012, 5, 339-352. [CrossRef]

144. Lopez, A.B.; Van Eck, J.; Conlin, B.J.; Paolillo, D.J.; O’Neill, J.; Li, L. Effect of the cauliflower or transgene on carotenoid accumulation and chromoplast formation in transgenic potato tubers. J. Exp. Bot. 2008, 59, 213-223. [CrossRef]

145. D'Ambrosio, C.; Giorio, G.; Marino, I.; Merendino, A.; Petrozza, A.; Salfi, L.; Stigliani, A.L.; Cellini, F. Virtually complete conversion of lycopene into $\beta$-carotene in fruits of tomato plants transformed with the tomato lycopene $\beta$-cyclase (tlcy-b) cDNA. Plant Sci. 2004, 166, 207-214. [CrossRef]

146. Morris, W.L.; Ducreux, L.J.M.; Hedden, P.; Millam, S.; Taylor, M.A. Overexpression of a bacterial 1-deoxy-d-xylulose 5-phosphate synthase gene in potato tubers perturbs the isoprenoid metabolic network: Implications for the control of the tuber life cycle. J. Exp. Bot. 2006, 57, 3007-3018. [CrossRef]

147. Schmidt, M.A.; Parrott, W.A.; Hildebrand, D.F.; Berg, R.H.; Cooksey, A.; Pendarvis, K.; He, Y.; McCarthy, F.; Herman, E.M. Transgenic soya bean seeds accumulating $\beta$-carotene exhibit the collateral enhancements of oleate and protein content traits. Plant Biotechnol. J. 2015, 13, 590-600. [CrossRef]

148. Paul, J.Y.; Khanna, H.; Kleidon, J.; Hoang, P.; Geijskes, J.; Daniells, J.; Zaplin, E.; Rosenberg, Y.; James, A.; Mlalazi, B.; et al. Golden bananas in the field: Elevated fruit pro-vitamin a from the expression of a single banana transgene. Plant Biotechnol. J. 2017, 15, 520-532. [CrossRef]

149. Naqvi, S.; Zhu, C.; Farre, G.; Ramessar, K.; Bassie, L.; Breitenbach, J.; Perez Conesa, D.; Ros, G.; Sandmann, G.; Capell, T.; et al. Transgenic multivitamin corn through biofortification of endosperm with three vitamins representing three distinct metabolic pathways. Proc. Natl. Acad. Sci. USA 2009, 106, 7762-7767. [CrossRef]

150. Eastmond, P.; Koláčná, L.; Rawsthorne, S. Photosynthesis by developing embryos of oilseed rape (brassica napus 1.). J. Exp. Bot. 1996, 47, 1763-1769. [CrossRef]

151. Ruuska, S.A.; Schwender, J.; Ohlrogge, J.B. The capacity of green oilseeds to utilize photosynthesis to drive biosynthetic processes. Plant Physiol. 2004, 136, 2700-2709. [CrossRef]

152. Cahoon, E.B.; Hall, S.E.; Ripp, K.G.; Ganzke, T.S.; Hitz, W.D.; Coughlan, S.J. Metabolic redesign of vitamin e biosynthesis in plants for tocotrienol production and increased antioxidant content. Nat. Biotechnol. 2003, 21, 1082-1087. [CrossRef]

153. Gannon, B.; Kaliwile, C.; Arscott, S.A.; Schmaelzle, S.; Chileshe, J.; Kalungwana, N.; Mosonda, M.; Pixley, K.V.; Masi, C.; Tanumihardjo, S.A. Biofortified orange maize is as efficacious as a vitamin a supplement in zambian children even in the presence of high liver reserves of vitamin a: A community-based, randomized placebo-controlled trial. Am. J. Clin. Nutr. 2014, 100, 1541-1550. [CrossRef]

154. Palmer, A.C.; Healy, K.; Barffour, M.A.; Siamusantu, W.; Chileshe, J.; Schulze, K.J.; West, K.P., Jr.; Labrique, A.B. Provitamin a carotenoid-biofortified maize consumption increases pupillary responsiveness among zambian children in a randomized controlled trial. J. Nutr. 2016, 146, 2551-2558. [CrossRef]

155. DellaPenna, D. Biofortification of plant-based food: Enhancing folate levels by metabolic engineering. Proc. Natl. Acad. Sci. USA 2007, 104, 3675-3676. [CrossRef]

156. Basset, G.; Quinlivan, E.P.; Gregory, J.F.; Hanson, A.D. Folate synthesis and metabolism in plants and prospects for biofortification. Crop. Sci. Soc. Am. 2005, 45, 449-453. [CrossRef]

157. Ravanel, S.; Douce, R.; Rebeille, F. Metabolism of folates in plants. Adv. Bot. Res. 2011, 59, 67-106.

158. Bailey, L.B.; Gregory, J.F., III. Folate metabolism and requirements. J. Nutr. 1999, 129, 779-782. [CrossRef]

159. Poletta, F.A.; Rittler, M.; Saleme, C.; Campana, H.; Gili, J.A.; Pawluk, M.S.; Gimenez, L.G.; Cosentino, V.R.; Castilla, E.E.; Lopez-Camelo, J.S. Neural tube defects: Sex ratio changes after fortification with folic acid. PLoS ONE 2018, 13, e0193127. [CrossRef]

160. Eskes, T.K. From anemia to spina bifida-The story of folic acid. A tribute to professor richard smithells. Eur. J. Obstet. Gynecol. Reprod. Biol. 2000, 90, 119-123. [CrossRef]

161. Lucock, M. Folic acid: Nutritional biochemistry, molecular biology, and role in disease processes. Mol. Genet. Metab. 2000, 71, 121-138. [CrossRef]

162. Molloy, A.M.; Scott, J.M. Folates and prevention of disease. Public Health Nutr. 2001, 4, 601-609. [CrossRef]

163. Iyer, R.; Tomar, S.K. Folate: A functional food constituent. J. Food Sci. 2009, 74, R114-R122. [CrossRef]

164. Díaz de la Garza, R.; Quinlivan, E.P.; Klaus, S.M.J.; Basset, G.J.C.; Gregory, J.F.; Hanson, A.D. Folate biofortification in tomatoes by engineering the pteridine branch of folate synthesis. Proc. Natl. Acad. Sci. USA 2004, 101, 13720-13725. [CrossRef] 
165. Díaz de la Garza, R.I.; Gregory, J.F.; Hanson, A.D. Folate biofortification of tomato fruit. Proc. Natl. Acad. Sci. USA 2007, 104, 4218-4222. [CrossRef]

166. Hossain, T.; Rosenberg, I.; Selhub, J.; Kishore, G.; Beachy, R.; Schubert, K. Enhancement of folates in plants through metabolic engineering. Proc. Natl. Acad. Sci. USA 2004, 101, 5158-5163. [CrossRef]

167. Basset, G.; Quinlivan, E.P.; Ziemak, M.J.; Diaz De La Garza, R.; Fischer, M.; Schiffmann, S.; Bacher, A.; Gregory, J.F.; Hanson, A.D. Folate synthesis in plants: The first step of the pterin branch is mediated by a unique bimodular gtp cyclohydrolase i. Proc. Natl. Acad. Sci. USA 2002, 99, 12489-12494. [CrossRef]

168. Ramírez Rivera, N.G.; García-Salinas, C.; Aragão, F.J.L.; Díaz de la Garza, R.I. Metabolic engineering of folate and its precursors in mexican common bean (phaseolus vulgaris 1.). Plant Biotechnol. J. 2016, 14, 2021-2032. [CrossRef]

169. Dong, W.; Cheng, Z.J.; Lei, C.L.; Wang, X.L.; Wang, J.L.; Wang, J.; Wu, F.Q.; Zhang, X.; Guo, X.P.; Zhai, H.Q.; et al. Overexpression of folate biosynthesis genes in rice (oryza sativa l.) and evaluation of their impact on seed folate content. Plant Foods Hum. Nutr. 2014, 69, 379-385. [CrossRef]

170. Kiekens, F.; Blancquaert, D.; Devisscher, L.; Van Daele, J.; Stove, V.V.; Delanghe, J.R.; Van Der Straeten, D.; Lambert, W.E.; Stove, C.P. Folates from metabolically engineered rice: A long-term study in rats. Mol. Nutr. Food Res. 2015, 59, 490-500. [CrossRef]

171. De Steur, H.; Gellynck, X.; Blancquaert, D.; Lambert, W.; Van Der Straeten, D.; Qaim, M. Potential impact and cost-effectiveness of multi-biofortified rice in china. N. Biotechnol. 2012, 29, 432-442. [CrossRef]

172. De Steur, H.; Blancquaert, D.; Lambert, W.; Van Der Straeten, D.; Gellynck, X. Conceptual framework for ex-ante evaluation at the micro/macro level of gm crops with health benefits. Trends Food Sci. Technol. 2014, 39, 116-134. [CrossRef]

173. Nunes, A.C.S.; Kalkmann, D.C.; Aragão, F.J.L. Folate biofortification of lettuce by expression of a codon optimized chicken gtp cyclohydrolase i gene. Transgenic Res. 2009, 18, 661. [CrossRef]

174. Blancquaert, D.; Storozhenko, S.; Van Daele, J.; Stove, C.; Visser, R.G.F.; Lambert, W.; Van Der Straeten, D. Enhancing pterin and para-aminobenzoate content is not sufficient to successfully biofortify potato tubers and arabidopsis thaliana plants with folate. J. Exp. Bot. 2013, 64, 3899-3909. [CrossRef]

175. Storozhenko, S.; De Brouwer, V.; Volckaert, M.; Navarrete, O.; Blancquaert, D.; Zhang, G.-F.; Lambert, W.; Van Der Straeten, D. Folate fortification of rice by metabolic engineering. Nat. Biotechnol. 2007, 25, 1277-1279. [CrossRef]

176. Roth, J.R.; Lawrence, J.G.; Bobik, T.A. Cobalamin (coenzyme b12): Synthesis and biological significance. Annu. Rev. Microbiol. 1996, 50, 137-181. [CrossRef]

177. Watanaba, F. Vitamin b12 sources and bioavailability. Exp. Biol. Med. 2007, 232, 1266-1274. [CrossRef]

178. Woo, K.S.; Kwok, T.C.Y.; Celermajer, D.S. Vegan diet, subnormal vitamin b-12 status and cardiovascular health. Nutrients 2014, 6, 3259-3273. [CrossRef]

179. Masalha, R.; Chudakov, B.; Morad, M.; Rudoy, I.; Volkov, I.; Wirguin, I. Cobalamin-responsive psychosis as the sole manifestation of vitamin b12 deficiency. Isr. Med Assoc. J. 2001, 9, 701-703.

180. Biemans, E.; Hart, H.E.; Rutten, G.E.H.M.; Cuellar Renteria, V.G.; Kooijman-Buiting, A.M.J.; Beulens, J.W.J. Cobalamin status and its relation with depression, cognition and neuropathy in patients with type 2 diabetes mellitus using metformin. Acta Diabetol. 2015, 52, 383-393. [CrossRef]

181. Pruthi, R.K.; Tefferi, A. Pernicious anemia revisited. Mayo Clin. Proc. 1994, 69, 144-150. [CrossRef]

182. Warren, M.J.; Raux, E.; Schubert, H.L.; Escalante-Semerena, J.C. The biosynthesis of adenosylcobalamin (vitamin b12). Nat. Prod. Rep. 2002, 19, 390-412. [CrossRef]

183. McGoldrick, H.M.; Roessner, C.A.; Raux, E.; Lawrence, A.D.; McLean, K.J.; Munro, A.W.; Santabarbara, S.; Rigby, S.E.J.; Heathcote, P.; Scott, A.I.; et al. Identification and characterization of a novel vitamin b12 (cobalamin) biosynthetic enzyme (cobz) from rhodobacter capsulatus, containing flavin, heme, and fe-s cofactors. J. Biol. Chem. 2005, 280, 1086-1094. [CrossRef]

184. Warren, M.J. Finding the final pieces of the vitamin $b_{12}$ biosynthetic jigsaw. Proc. Natl. Acad. Sci. USA 2006, 103, 4799-4800. [CrossRef]

185. Lawrence, A.D.; Nemoto-Smith, E.; Deery, E.; Baker, J.A.; Schroeder, S.; Brown, D.G.; Tullet, J.M.A.; Howard, M.J.; Brown, I.R.; Smith, A.G.; et al. Construction of fluorescent analogs to follow the uptake and distribution of cobalamin (vitamin b12) in bacteria, worms, and plants. Cell Chem. Biol. 2018, 25, 941-951. [CrossRef] 
186. Fang, H.; Kang, J.; Zhang, D. Microbial production of vitamin b(12): A review and future perspectives. Microb. Cell Factories 2017, 16, 15. [CrossRef]

187. Fenech, M.; Amaya, I.; Valpuesta, V.; Botella, M.A. Vitamin c content in fruits: Biosynthesis and regulation. Front. Plant Sci. 2019, 9, 2006. [CrossRef]

188. Duarte, T.L.; Lunec, J. Reviewpart of the series: From dietary antioxidants to regulators in cellular signalling and gene expressionreview: When is an antioxidant not an antioxidant? A review of novel actions and reactions of vitamin c. Free Radic. Res. 2005, 39, 671-686. [CrossRef]

189. Li, Y.; Schellhorn, H.E. New developments and novel therapeutic perspectives for vitamin c. J. Nutr. 2007, 137, 2171-2184. [CrossRef]

190. Harrison, F.E.; May, J.M. Vitamin c function in the brain: Vital role of the ascorbate transporter svct2. Free Radic. Biol. Med. 2009, 46, 719-730. [CrossRef]

191. Young, J.I.; Züchner, S.; Wang, G. Regulation of the epigenome by vitamin c. Annu. Rev. Nutr. 2015, 35, 545-564. [CrossRef]

192. Camarena, V.; Wang, G. The epigenetic role of vitamin c in health and disease. Cell. Mol. Life Sci. 2016, 73, 1645-1658. [CrossRef]

193. Du, J.; Cullen, J.J.; Buettner, G.R. Ascorbic acid: Chemistry, biology and the treatment of cancer. Biochim. Biophys. Acta Rev. Cancer 2012, 1826, 443-457. [CrossRef]

194. Leong, S.Y.; Oey, I. Effects of processing on anthocyanins, carotenoids and vitamin c in summer fruits and vegetables. Food Chem. 2012, 133, 1577-1587. [CrossRef]

195. Da Silva Dias, J.C. Nutritional and health benefits of carrots and their seed extracts. Food Nutr. Sci. 2014, 5, 2147-2156. [CrossRef]

196. Müller-Moulé, P.; Conklin, P.L.; Niyogi, K.K. Ascorbate deficiency can limit violaxanthin de-epoxidase activity in vivo. Plant Physiol. 2002, 128, 970-977. [CrossRef]

197. Müller-Moulé, P.; Golan, T.; Niyogi, K.K. Ascorbate-deficient mutants of arabidopsis grow in high light despite chronic photooxidative stress. Plant Physiol. 2004, 134, 1163-1172. [CrossRef]

198. Esteban, R.; Moran, J.F.; Becerril, J.M.; García-Plazaola, J.I. Versatility of carotenoids: An integrated view on diversity, evolution, functional roles and environmental interactions. Environ. Exp. Bot. 2015, 119, 63-75. [CrossRef]

199. Wheeler, G.L.; Jones, M.A.; Smirnoff, N. The biosynthetic pathway of vitamin c in higher plants. Nature 1998, 393, 365-369. [CrossRef]

200. Lorence, A.; Chevone, B.I.; Mendes, P.; Nessler, C.L. Inositol oxygenase offers a possible entry point into plant ascorbate biosynthesis. Plant Physiol. 2004, 134, 1200-1205. [CrossRef]

201. Wolucka, B.A.; Van Montagu, M. Gdp-mannose 3',5'-epimerase forms gdp-l-gulose, a putative intermediate for the de novo biosynthesis of vitamin c in plants. J. Biol. Chem. 2003, 278, 47483-47490. [CrossRef]

202. Wolucka, B.A.; Van Montagu, M. The vtc2 cycle and the de novo biosynthesis pathways for vitamin $\mathrm{c}$ in plants: An opinion. Phytochemistry 2007, 68, 2602-2613. [CrossRef]

203. Agius, F.; González-Lamothe, R.; Caballero, J.L.; Muñoz-Blanco, J.; Botella, M.A.; Valpuesta, V. Engineering increased vitamin c levels in plants by overexpression of a d-galacturonic acid reductase. Nat. Biotechnol. 2003, 21, 177-181. [CrossRef]

204. Loewus, F.A. Biosynthesis and metabolism of ascorbic acid in plants and of analogs of ascorbic acid in fungi. Phytochemistry 1999, 52, 193-210. [CrossRef]

205. Conklin, P.L.; Norris, S.R.; Wheeler, G.L.; Williams, E.H.; Smirnoff, N.; Last, R.L. Genetic evidence for the role of gdp-mannose in plant ascorbic acid (vitamin c) biosynthesis. Proc. Natl. Acad. Sci. USA 1999, 96, 4198-4203. [CrossRef]

206. Linster, C.L.; Gomez, T.A.; Christensen, K.C.; Adler, L.N.; Young, B.D.; Brenner, C.; Clarke, S.G. Arabidopsis vtc2 encodes a gdp-l-galactose phosphorylase, the last unknown enzyme in the smirnoff-wheeler pathway to ascorbic acid in plants. J. Biol. Chem. 2007, 282, 18879-18885. [CrossRef]

207. Troesch, B.; Hoeft, B.; McBurney, M.; Eggersdorfer, M.; Weber, P. Dietary surveys indicate vitamin intakes below recommendations are common in representative western countries. Br. J. Nutr. 2012, 108, 692-698. [CrossRef]

208. Ishikawa, T.; Dowdle, J.; Smirnoff, N. Progress in manipulating ascorbic acid biosynthesis and accumulation in plants. Physiol. Plant. 2006, 126, 343-355. [CrossRef] 
209. Zhang, C.; Liu, J.; Zhang, Y.; Cai, X.; Gong, P.; Zhang, J.; Wang, T.; Li, H.; Ye, Z. Overexpression of slgmes leads to ascorbate accumulation with enhanced oxidative stress, cold, and salt tolerance in tomato. Plant Cell Rep. 2011, 30, 389-398. [CrossRef]

210. Bulley, S.; Wright, M.; Rommens, C.; Yan, H.; Rassam, M.; Lin-Wang, K.; Andre, C.; Brewster, D.; Karunairetnam, S.; Allan, A.C.; et al. Enhancing ascorbate in fruits and tubers through over-expression of the l-galactose pathway gene gdp-l-galactose phosphorylase. Plant Biotechnol. J. 2012, 10, 390-397. [CrossRef]

211. Bulley, S.M.; Rassam, M.; Hoser, D.; Otto, W.; Schünemann, N.; Wright, M.; MacRae, E.; Gleave, A.; Laing, W. Gene expression studies in kiwifruit and gene over-expression in arabidopsis indicates that gdp-l-galactose guanyltransferase is a major control point of vitamin c biosynthesis. J. Exp. Bot. 2009, 60, 765-778. [CrossRef]

212. Locato, V.; Cimini, S.; De Gara, L. Strategies to increase vitamin c in plants: From plant defense perspective to food biofortification. Front. Plant Sci. 2013, 4, 152. [CrossRef]

213. Pignocchi, C.; Fletcher, J.M.; Wilkinson, J.E.; Barnes, J.D.; Foyer, C.H. The function of ascorbate oxidase in tobacco. Plant Physiol. 2003, 132, 1631-1641. [CrossRef]

214. Yamamoto, A.; Bhuiyan, M.N.H.; Waditee, R.; Tanaka, Y.; Esaka, M.; Oba, K.; Jagendorf, A.T.; Takabe, T. Suppressed expression of the apoplastic ascorbate oxidase gene increases salt tolerance in tobacco and arabidopsis plants. J. Exp. Bot. 2005, 56, 1785-1796. [CrossRef]

215. Chen, Z.; Young, T.E.; Ling, J.; Chang, S.-C.; Gallie, D.R. Increasing vitamin c content of plants through enhanced ascorbate recycling. Proc. Natl. Acad. Sci. USA 2003, 100, 3525-3530. [CrossRef]

216. Hemavathi, A.; Upadhyaya, C.P.; Akula, N.; Young, K.E.; Chun, S.C.; Kim, D.H.; Park, S.W. Enhanced ascorbic acid accumulation in transgenic potato confers tolerance to various abiotic stresses. Biotechnol. Lett. 2010, 32, 321-330. [CrossRef]

217. Jain, A.K.; Nessler, C.L. Metabolic engineering of an alternative pathway for ascorbic acid biosynthesis in plants. Mol. Breed. 2000, 6, 73-78. [CrossRef]

218. Radzio, J.A.; Lorence, A.; Chevone, B.I.; Nessler, C.L. L-gulono-1,4-lactone oxidase expression rescues vitamin c-deficient arabidopsis (vtc) mutants. Plant Mol. Biol. 2003, 53, 837-844. [CrossRef]

219. Suekawa, M.; Fujikawa, Y.; Inoue, A.; Kondo, T.; Uchida, E.; Koizumi, T.; Esaka, M. High levels of expression of multiple enzymes in the smirnoff-wheeler pathway are important for high accumulation of ascorbic acid in acerola fruits. Biosci. Biotechnol. Biochem. 2019, 83, 1713-1716. [CrossRef]

220. Schwanz, P.; Kimball, B.A.; Idso, S.B.; Hendrix, D.L.; Polle, A. Antioxidants in sun and shade leaves of sour orange trees (citrus aurantium) after long-term acclimation to elevated $\mathrm{CO}_{2}$. J. Exp. Bot. 1996, 47, 1941-1950. [CrossRef]

221. Liu, J.-X.; Feng, K.; Wang, G.-L.; Wu, X.-J.; Duan, A.-Q.; Yin, L.; Shen, D.; Xu, Z.-S.; Xiong, A.-S. Effect of elevated $\mathrm{CO} 2$ on ascorbate accumulation and the expression levels of genes involved in ascorbate metabolism in celery. J. Plant Growth Regul. 2019, 1-15. [CrossRef]

222. Robinson, J.M.; Sicher, R.C. Antioxidant levels decrease in primary leaves of barley during growth at ambient and elevated carbon dioxide levels. Int. J. Plant Sci. 2004, 165, 965-972. [CrossRef]

223. Cahoon, E.B.; Coughlan, S.J.; Cahoon, R.E.; Butler, K.H. Compositions and Methods for Altering Tocotrienal Content. French Patent WO2003082899A8, 30 June 2005.

224. Cober, E.R.; Morrison, M.J. Soybean yield and seed composition changes in response to increasing atmospheric $\mathrm{CO}_{2}$ concentration in short-season canada. Plants 2019, 8, 250. [CrossRef]

225. Myers, S.S.; Zanobetti, A.; Kloog, I.; Huybers, P.; Leakey, A.D.B.; Bloom, A.J.; Carlisle, E.; Dietterich, L.H.; Fitzgerald, G.; Hasegawa, T.; et al. Increasing $\mathrm{CO}_{2}$ threatens human nutrition. Nature 2014, 510, 139. [CrossRef]

226. Zhu, C.; Kobayashi, K.; Loladze, I.; Zhu, J.; Jiang, Q.; Xu, X.; Liu, G.; Seneweera, S.; Ebi, K.L.; Drewnowski, A.; et al. Carbon dioxide $\left(\mathrm{CO}_{2}\right)$ levels this century will alter the protein, micronutrients, and vitamin content of rice grains with potential health consequences for the poorest rice-dependent countries. Sci. Adv. 2018, 4, eaaq1012. [CrossRef]

227. Aglawe, S.B.; Barbadikar, K.M.; Mangrauthia, S.K.; Madhav, M.S. New breeding technique "genome editing" for crop improvement: Applications, potentials and challenges. 3 Biotech 2018, 8, 336. [CrossRef]

228. Georges, F.; Ray, H. Genome editing of crops: A renewed opportunity for food security. GM Crop. Food 2017, 8,1-12. [CrossRef]

229. Wilson, F.; Harrison, K.; Armitage, A.D.; Simkin, A.J.; Harrison, R.J. Crispr/cas9-mediated mutagenesis of phytoene desaturase in diploid and octoploid strawberry. BMC Plant Methods 2019, 15, 45. [CrossRef] 
230. Exposito-Rodriguez, M.; Laissue, P.P.; Lopez-Calcagno, P.E.; Mullineaux, P.M.; Raines, C.A.; Simkin, A.J. Development of pgemini, a plant gateway destination vector allowing the simultaneous integration of two cdna via a single lr-clonase reaction. Plants 2017, 6, 55. [CrossRef]

231. Engler, C.; Gruetzner, R.; Kandzia, R.; Marillonnet, S. Golden gate shuffling: A one-pot DNA shuffling method based on type iis restriction enzymes. PLoS ONE 2009, 4, e5553. [CrossRef]

232. Engler, C.; Kandzia, R.; Marillonnet, S. A one pot, one step, precision cloning method with high throughput capability. PLoS ONE 2008, 3, e3647. [CrossRef]

233. Engler, C.; Youles, M.; Gruetzner, R.; Ehnert, T.M.; Werner, S.; Jones, J.D.; Patron, N.J.; Marillonnet, S. A golden gate modular cloning toolbox for plants. ACS Synth Biol. 2014, 3, 839-843. [CrossRef]

234. Marillonnet, S.; Werner, S. Assembly of multigene constructs using golden gate cloning. In Glyco-Engineering: Methods and Protocols; Castilho, A., Ed.; Springer: New York, NY, USA, 2015.

235. Alotaibi, S.S.; Sparks, C.A.; Parry, M.A.J.; Simkin, A.J.; Raines, C.A. Identification of leaf promoters for use in transgenic wheat. Plants 2018, 7, 27. [CrossRef]

236. Mukherjee, S.; Stasolla, C.; Brule-Babel, A.; Ayele, B.T. Isolation and characterization of rubisco small subunit gene promoter from common wheat (triticum aestivum 1.). Plant Signal. Behav. 2015, 10, e989033. [CrossRef]

237. Alotaibi, S.S.; Alyassi, H.; Alshehawi, A.; Gaber, A.; Hassan, M.M.; Aljuaid, B.S.; Simkin, A.J.; Raines, C.A. Functional analysis of sbpase gene promoter in transgenic wheat under different growth conditions. Biotechnology 2019, 1, 15-23. [CrossRef]

238. Simkin, A.J.; Qian, T.; Caillet, V.; Michoux, F.; Ben Amor, M.; Lin, C.; Tanksley, S.; McCarthy, J. Oleosin gene family of coffea canephora: Quantitative expression analysis of five oleosin genes in developing and germinating coffee grain. J. Plant Physiol. 2006, 163, 691-708. [CrossRef]

239. Simkin, A.J.; McCarthy, J.; Petiard, V.; Tanksley, S.; Lin, C. Oleosin Genes and Promoters from Coffee. French Patent WO2,007,005,928, 11 January 2007.

240. Kuntz, M.; Chen, H.C.; Simkin, A.J.; Römer, S.; Shipton, C.A.; Drake, R.; Schuch, W.; Bramley, P.M. Upregulation of two ripening-related genes from a non-climacteric plant (pepper) in a transgenic climacteric plant (tomato). Plant J. 1998, 13, 351-361. [CrossRef]

241. Regis, E. Golden Rice: The Imperiled Birth of a Gmo Superfood; Johns Hopkins University Press: Baltimore, MD, USA, 2019.

242. Davison, J. Gm plants: Science, politics and ec regulations. Plant Sci. 2010, 178, 94-98. [CrossRef]

243. Davison, J.; Ammann, K. New gmo regulations for old: Determining a new future for eu crop biotechnology. GM Crop. Food 2017, 8, 13-34. [CrossRef]

244. Smart, R.D.; Blum, M.; Wesseler, J. Trends in approval times for genetically engineered crops in the United States and the European Union. J. Agric. Econ. 2017, 68, 182-198. [CrossRef] 